\title{
Continued Documentation of Ancestral Caddo Ceramic Vessels from East Texas Caddo Sites in the Buddy Jones Collection at the Gregg County Historical Museum
}

Timothy K. Perttula

R. Bo Nelson

Tejas Archaeology

Follow this and additional works at: https://scholarworks.sfasu.edu/ita

Part of the American Material Culture Commons, Archaeological Anthropology Commons, Environmental Studies Commons, Other American Studies Commons, Other Arts and Humanities Commons, Other History of Art, Architecture, and Archaeology Commons, and the United States History Commons

Tell us how this article helped you.

This Article is brought to you for free and open access by the Center for Regional Heritage Research at SFA ScholarWorks. It has been accepted for inclusion in Index of Texas Archaeology: Open Access Gray Literature from the Lone Star State by an authorized editor of SFA ScholarWorks. For more information, please contact cdsscholarworks@sfasu.edu. 
Continued Documentation of Ancestral Caddo Ceramic Vessels from East Texas Caddo Sites in the Buddy Jones Collection at the Gregg County Historical Museum

Creative Commons License

(c) (1) \& 8

This work is licensed under a Creative Commons Attribution-NonCommercial 4.0 International License 


\title{
Continued Documentation of Ancestral Caddo Ceramic Vessels from East Texas Caddo Sites in the Buddy Jones Collection at the Gregg County Historical Museum
}

\author{
Timothy K. Perttula and Bo Nelson
}

\section{Introduction}

In this article, we document 33 recently acquired ancestral Caddo ceramic vessels to the Buddy Jones Collection held by the Gregg County Historical Museum in Longview, Texas. These vessels had until recently been kept separate from the remainder of the collection. We documented this part of the vessel collections in April 2018.

The documented vessels with site provenience information $(\mathrm{n}=27)$ are from sites in Anderson, Cherokee, and Harrison counties, namely: the Pipe (41AN67), Mud Creek, and H. C. Slider sites in the Neches River basin; the Darco site in the Sabine River basin; and the Tejas Village site in the Big Cypress Creek basin (Figure 1); other vessels from these sites were previously documented by Perttula (2011b) and Perttula and Nelson (2013a, 2013b). Six vessels are from unknown East Texas sites.

\section{Natural Regions of Texas}

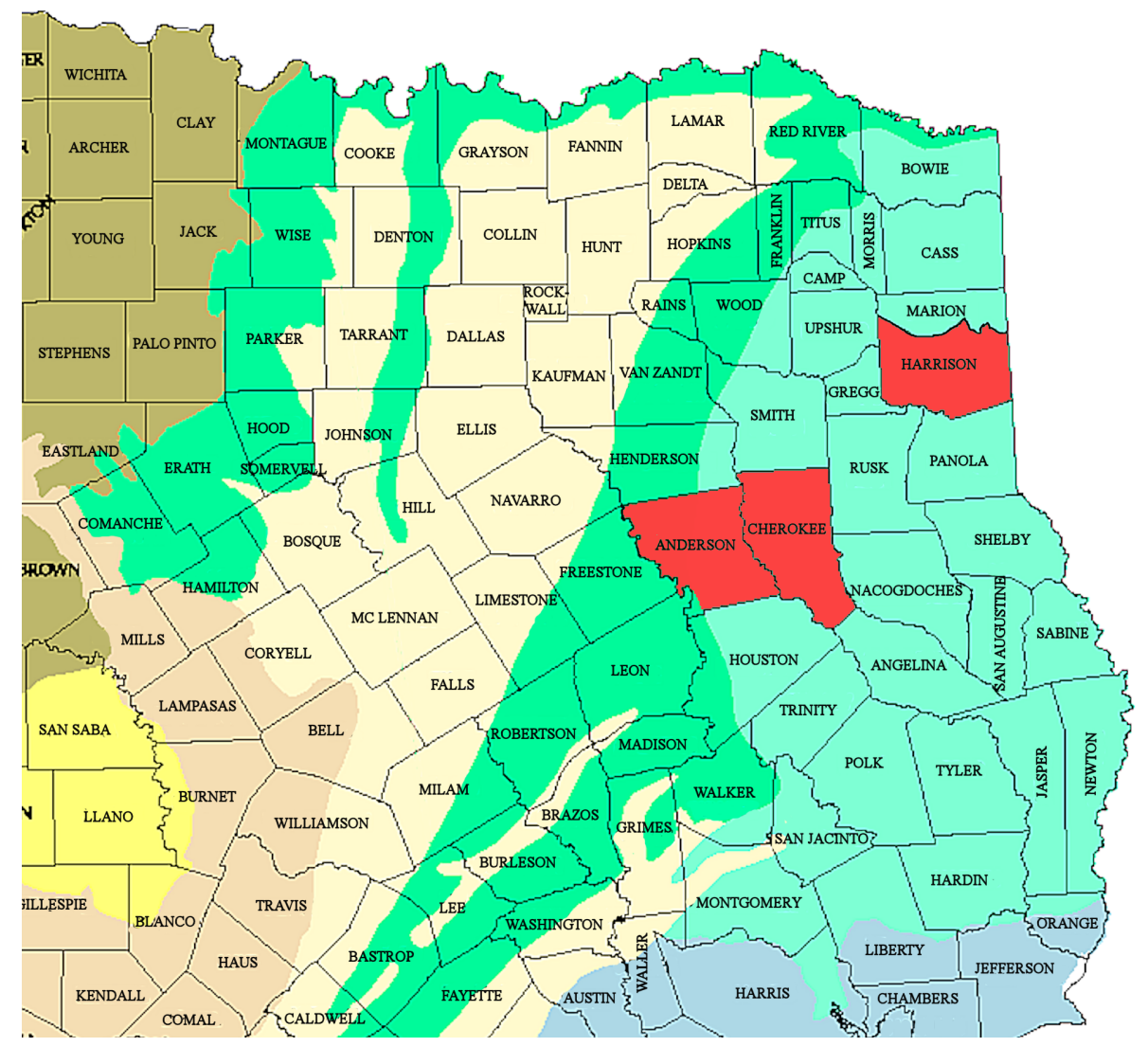

Figure 1. General location of sites with vessels in East Texas discussed in this article. 


\section{Methods of Ceramic Vessel Analysis}

As with other ancestral Caddo ceramic vessel documentation studies completed of ceramic assemblages from East Texas sites in recent years, the following consistent set of attributes were employed in the study and documentation of the ceramic vessels from the Buddy Jones Collection at the Gregg County Historical Museum:

Non-plastics: Deliberate and indeterminate materials in the paste (Rice 1987:411), including a variety of tempers (i.e., grog or crushed sherds, bone, hematite, and shell, as well as combinations of different temper inclusions) and "particulate matter of some size." The grog, bone, hematite, or shell appears to have been deliberately added to the paste as tempers. The bone or shell used for temper had been burned and calcined, then crushed, before it was added to the paste.

Vessel Form: Vessel form categories include open containers (bowls of several sizes, including effigy bowls, carinated bowls, and compound bowls) and restricted containers, including jars and bottles, as well as plates. As restricted containers, jars allow access by hand, but bottles do not (Brown 1996:335). Other form attributes that were recorded include the rim profile (outflaring or everted, vertical or standing, and inverted), lip profile (rolled to the exterior, rounded, flat, or thinned), and base shape (flat or rounded).

Core Colors: Observations on ceramic cross-section colors permit consideration of oxidation patterns (Teltser 1993:Figure 2A-H; Perttula 2005:Figure 5-30), and thus the conditions under which the vessel was fired and then cooled after firing. Comments are included for these attributes on the presence and location of fire-clouding, sooting or smudging from cooking use (Skibo 1992), and the preservation of any charred organic remains.

Wall Thickness: Thickness was recorded in millimeters, using a vernier caliper, at the lip, along the rim, at several points along the body when possible, and at the base when possible (only for the vessels that were not complete).

Interior and Exterior Surface Treatment: The primary methods of finishing the surface of the vessels includes either smoothing, burnishing, and rarely polishing (Rice 1987:138). Brushing, while a popular method of roughening the surface (particularly the body) of large and small Middle (ca. A.D. 1200-1450) and Late Caddo (ca. A.D. 1450-1680) period cooking jars in several parts of the Caddo area (Perttula 2015), is here considered a decorative treatment rather than solely a functional surface treatment (cf. Rice 1987:138), although not all Caddo ceramic analysts treat brushing as a decorative treatment. Smoothing creates "a finer and more regular surface... [and] has a matte rather than a lustrous finish" (Rice 1987:138). Burnishing, on the other hand, creates an irregular lustrous finish marked by parallel facets left by the burnishing tool (perhaps a pebble or bone). A polished surface treatment is marked by a uniform and highly lustrous surface finish, done when the vessel is dry, but without "the pronounced parallel facets produced by burnishing leather-hard clay" (Rice 1987:138).

The application of a hematite-rich clay slip (Ferring and Perttula 1987), either red or black after firing in an oxidizing or reducing (i.e., low-oxygen) environment, respectively, is another form of surface treatment noted in many East Texas assemblage. On these vessels, the clay slip is more frequently applied on the vessel exterior, or on both surfaces, than on the interior surface, and then was burnished after it was leather-hard or dry. 
Height and Orifice Diameter: These attributes, measured in centimeters, were recorded with a ruler.

Diameter at Bottom of Rim and Base Diameter: Also recorded in millimeters using a ruler, these attributes permit characterization of the overall contour and shape of the vessel.

Volume: With measurements of height and orifice diameter obtained from the vessels, as well as other measurements of size (i.e., base diameter and maximum body width), volumes were estimated by comparison with known vessel volumes of specific forms (i.e., carinated bowl, jar, bottle, compound bowl, and bowl) in many other recently documented Caddo vessel assemblages.

Base Diameter and Shape: these attributes were either measured in centimeters or by shape attributes: circular or square, and flat, rounded (convex), or concave.

Decoration: Decorative techniques present in the vessel collection include engraving, incising, trailing, punctating, pinching, brushing, and appliquéing, and on certain vessels, combinations of decorative techniques (i.e., incised-punctated) created the decorative elements and motifs. Engraving was done with a sharp tool when the vessel was either leather-hard, or after it was fired, as were the tick marks often seen on vessels in this collection, while the other decorative techniques were executed with tools (trailing, incising, and punctation), by adding strips of clay to the wet body (appliqué), using frayed sticks or grass stems (brushing) dragged across the body surface, or fingernails (certain forms of punctations and pinching), when the vessel was wet or still plastic. Excising is considered a form of engraved decoration, where the clay is deliberately and closely marked/scraped and carved away with a sharp tool, usually to create triangular elements, tick marks, or excised punctations.

Use of Pigments: Another form of vessel decoration is the use of red (hematite or ochre) or white (kaolin clay) clay pigments that have been smeared or rubbed into the engraved lines of certain vessels.

Type: The kinds of ceramic types and defined varieties in the Buddy Jones collections follow Suhm and Jelks (1962), Perttula (2005, 2011a), and Fields et al. (2014).

\section{Ceramic Vessels}

\section{Pipe Site or Blackburn Crossing Site (41AN67)}

Buddy Calvin Jones excavated a Late Caddo cemetery and midden site he called the Blackburn Crossing site, in Anderson County, Texas, in March 1968. His notes indicate that a total of 21 Caddo burials were excavated at the site, and the burials were situated primarily around a midden of unknown dimensions (Perttula 2011b:Figure 1). Jones' notes do not specify how many of the burials he excavated at the Pipe site, but one photograph in the records suggests he excavated at least three. Jones' notes were sufficient to link his site with the Ferguson site (41AN67) excavated by Anderson et al. (1974:Figure 58). Because of the mass of elbow pipe sherds (from between 32-36 pipes) found with one burial, Perttula (2011b) renamed the site the Pipe site. Analysis of the ceramic vessel sherd assemblage from the site discussed by Anderson et al. (1974), the available radiocarbon dates from the site, and the many pipes, the Pipe site was occupied between ca. A.D. 1480-1560 by Frankston phase Caddo peoples (Perttula 2011a:Table 2). 
SITE NAME OR SITE NUMBER: Pipe site

VESSEL NO.: 2003.08.3201

VESSEL FORM: Jar

NON-PLASTICS AND PASTE: grog

RIM AND LIP FORM: Direct rim and rounded lip

CORE COLOR: $\mathrm{F}$ (fired in a reducing environment and cooled in the open air)

INTERIOR SURFACE COLOR: reddish-brown

EXTERIOR SURFACE COLOR: reddish-brown

WALL THICKNESS (IN MM): rim, $6.2 \mathrm{~mm}$

INTERIOR SURFACE TREATMENT: smoothed

EXTERIOR SURFACE TREATMENT: none

HEIGHT (IN CM): 11.5

ORIFICE DIAMETER (IN CM): 10.8

DIAMETER AT BOTTOM OF RIM OR NECK (IN CM): 11.5

BASE DIAMETER (IN CM) AND SHAPE OF BASE: $5.1 \mathrm{~cm}$, circular and flat

ESTIMATED VOLUME (IN LITERS): 0.75

DECORATION (INCLUDING MOTIF AND ELEMENTS WHEN APPARENT): The vessel has a single row of tool punctations beneath the vessel lip as well as four vertical rows of pinched ridges around the vessel that extend to just above the vessel base. These pinched ridges divide the vessel body into four panels filled with diagonal brushing marks (Figure 2).

\section{PIGMENT USE AND LOCATION ON VESSEL:} none

TYPE AND VARIETY (IF KNOWN):

Unidentified utility ware

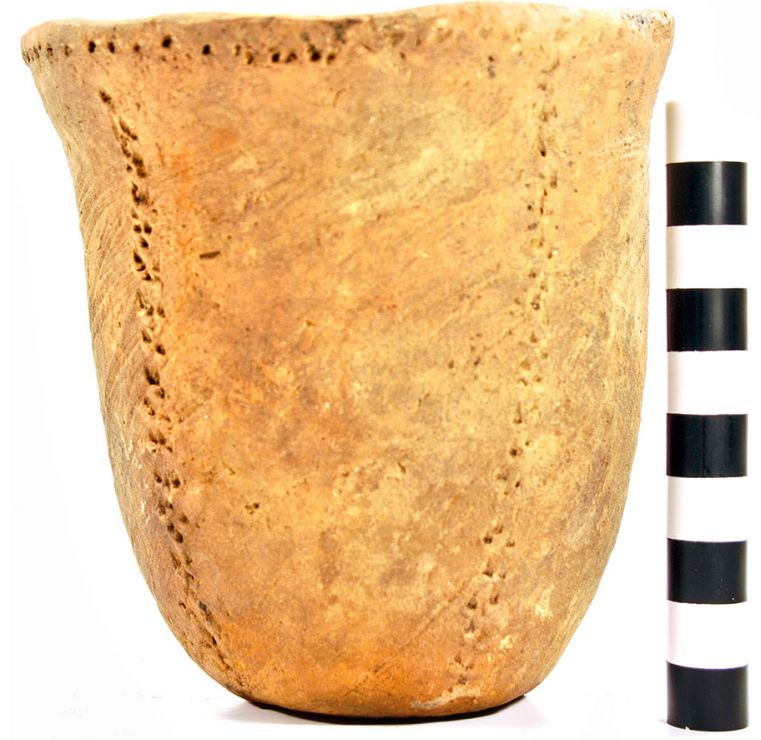

Figure 2. Brushed-punctated-pinched jar from the Pipe site, Anderson County, Texas. 
SITE NAME OR SITE NUMBER: Pipe site

VESSEL NO.: 2003.08.3202

VESSEL FORM: Bowl with interior thickened rim (1.3 cm in width) (Figure 3a-b)

NON-PLASTICS AND PASTE: grog

RIM AND LIP FORM: Direct rim and rounded lip

CORE COLOR: $\mathrm{F}$ (fired in a reducing environment and cooled in the open air)

INTERIOR SURFACE COLOR: brown; fire clouds on the rim and body

EXTERIOR SURFACE COLOR: brown; fire clouds on the body

WALL THICKNESS (IN MM): rim, 7.2 mm

INTERIOR SURFACE TREATMENT: smoothed

EXTERIOR SURFACE TREATMENT: smoothed

HEIGHT (IN CM): 2.2

ORIFICE DIAMETER (IN CM): 10.6

DIAMETER AT BOTTOM OF RIM OR NECK (IN CM): N/A

BASE DIAMETER (IN CM) AND SHAPE OF BASE: $5.8 \mathrm{~cm}$; circular and flat

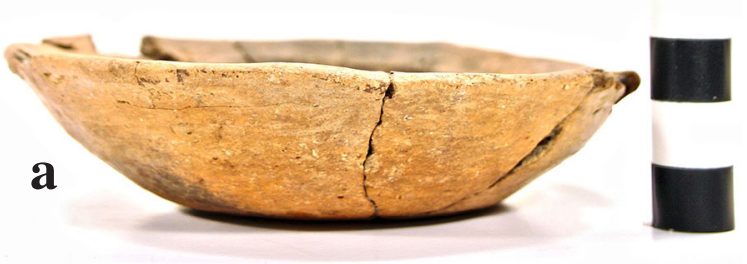

ESTIMATED VOLUME (IN LITERS): 0.1

DECORATION (INCLUDING MOTIF AND ELEMENTS WHEN APPARENT): Plain (Figure 3a)

PIGMENT USE AND LOCATION ON VESSEL: none

TYPE AND VARIETY (IF KNOWN):

Unidentified plain ware

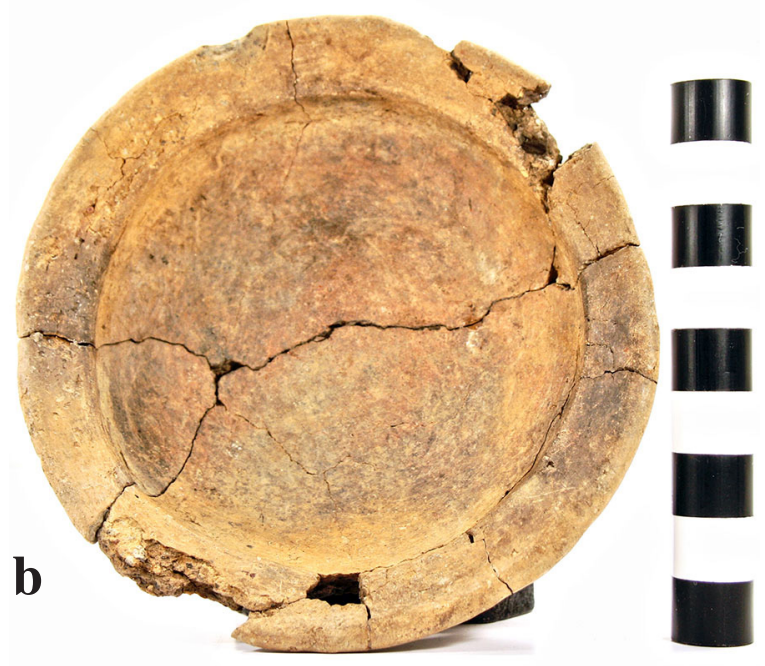

Figure 3. Plain bowl from the Pipe site: a, side view; $\mathrm{b}$, interior view 
SITE NAME OR SITE NUMBER: Pipe site

VESSEL NO.: 200.3.08.3203

VESSEL FORM: Globular bowl

NON-PLASTICS AND PASTE: grog

RIM AND LIP FORM: Everted rim and a rounded, exterior folded lip; the lip is also scalloped

CORE COLOR: $\mathrm{F}$ (fired in a reducing environment and cooled in the open air)

INTERIOR SURFACE COLOR: brown; fire clouds on the rim, body, and base

EXTERIOR SURFACE COLOR: brown; fire clouds on the rim, body, and base

WALL THICKNESS (IN MM): rim, $5.4 \mathrm{~mm}$; body, $6.1 \mathrm{~mm}$; base, $7.7 \mathrm{~mm}$

INTERIOR SURFACE TREATMENT: smoothed

EXTERIOR SURFACE TREATMENT: smoothed

HEIGHT (IN CM): 6.4

ORIFICE DIAMETER (IN CM): 10.8

DIAMETER AT BOTTOM OF RIM OR NECK (IN CM): 10.6

BASE DIAMETER (IN CM) AND SHAPE OF BASE: 7.6

ESTIMATED VOLUME (IN LITERS): 0.3

DECORATION (INCLUDING MOTIF AND ELEMENTS WHEN APPARENT): The vessel has a single rim panel defined by upper and lower horizontal engraved lines. Within the panel are a series of vertical engraved lines, several of which form columns with diagonal, diagonal opposed, or cross-hatched engraved lines (Figure 4).

PIGMENT USE AND LOCATION ON VESSEL: none

TYPE AND VARIETY (IF KNOWN):

Unidentified fine ware

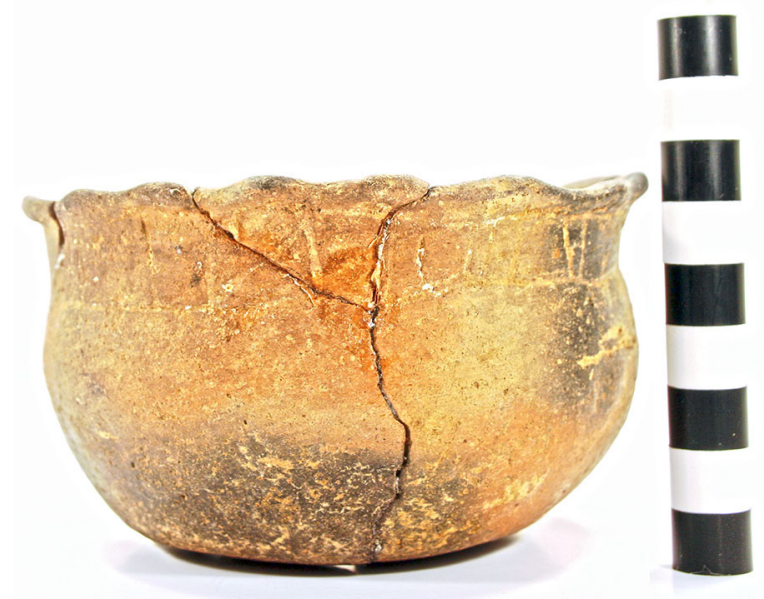

Figure 4. Engraved globular bowl from the Pipe site. 
SITE NAME OR SITE NUMBER: Pipe site

VESSEL NO.: 2003.08.3204

VESSEL FORM: Globular carinated bowl

NON-PLASTICS AND PASTE: grog and bone

RIM AND LIP FORM: Direct rim and rounded lip

CORE COLOR: $\mathrm{F}$ (fired in a reducing environment and cooled in the open air)

INTERIOR SURFACE COLOR: reddish-brown; fire clouds on the rim

EXTERIOR SURFACE COLOR: reddish-brown; organic residue on the rim and body

WALL THICKNESS (IN MM): rim, $6.2 \mathrm{~mm}$

INTERIOR SURFACE TREATMENT: smoothed

EXTERIOR SURFACE TREATMENT: burnished

HEIGHT (IN CM): 12.7

ORIFICE DIAMETER (IN CM): 14.2

DIAMETER AT BOTTOM OF RIM OR NECK (IN CM): 14.0

BASE DIAMETER (IN CM) AND SHAPE OF BASE: $8.0 \mathrm{~cm}$, circular and flat

ESTIMATED VOLUME (IN

LITERS): 1.1

DECORATION (INCLUDING

MOTIF AND ELEMENTS WHEN

APPARENT): The rim panel has three sets of ovals defined by hatched brackets. Within each oval is a small centrally-placed circle with single intersecting horizontal and vertical engraved lines (Figure 5). Between each oval are two sets of narrow vertical cross-hatched columns.

PIGMENT USE AND LOCATION ON VESSEL: none

TYPE AND VARIETY (IF KNOWN): Poynor Engraved, var. Lang (see Perttula 2011a:Figure 6-64f-g')

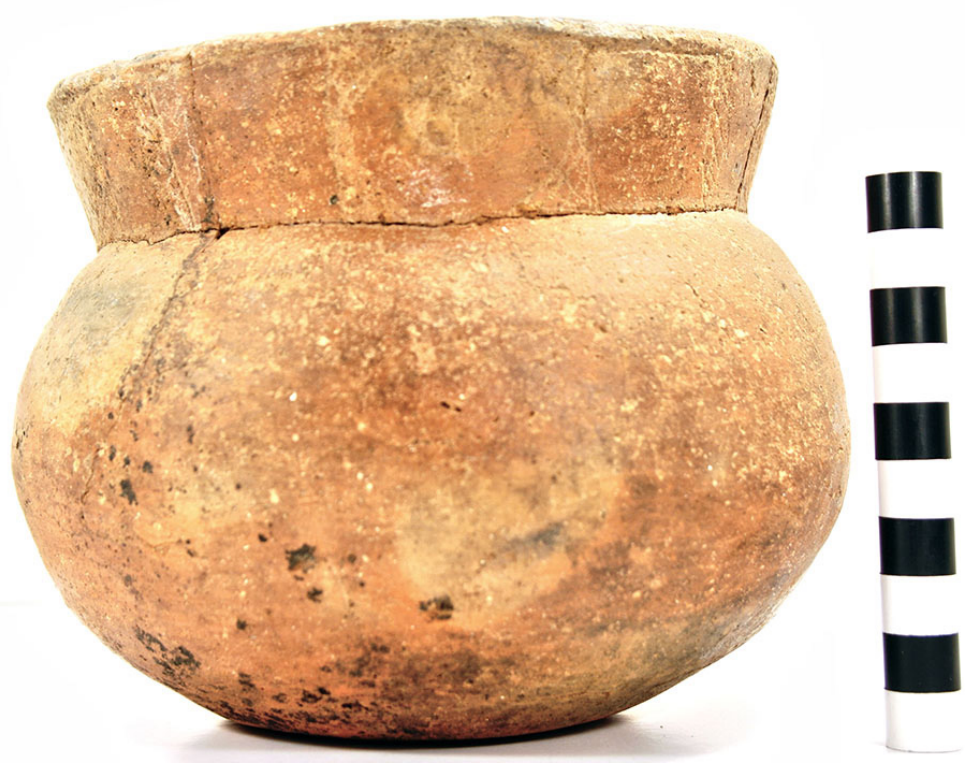

Figure 5. Poynor Engraved, var. Lang carinated bowl from the Pipe site. 
SITE NAME OR SITE NUMBER: Pipe site

VESSEL NO.: 2003.08.3205

VESSEL FORM: Bowl with rim peaks (Figure 6a)

NON-PLASTICS AND PASTE: grog

RIM AND LIP FORM: Direct rim and rounded lip

CORE COLOR: $\mathrm{F}$ (fired in a reducing environment and cooled in the open air)

INTERIOR SURFACE COLOR: reddish-brown

EXTERIOR SURFACE COLOR: reddish-brown; fire clouds on the body and base

WALL THICKNESS (IN MM): rim, $4.9 \mathrm{~mm}$

INTERIOR SURFACE TREATMENT: burnished

EXTERIOR SURFACE TREATMENT: burnished

HEIGHT (IN CM): $3.0 \mathrm{~cm} ; 3.8 \mathrm{~cm}$ at the rim peaks

ORIFICE DIAMETER (IN CM): 11.4

DIAMETER AT BOTTOM OF RIM OR NECK (IN $\mathrm{CM}): \mathrm{N} / \mathrm{A}$

BASE DIAMETER (IN CM) AND SHAPE OF BASE: $5.8 \mathrm{~cm}$, circular and flat

ESTIMATED VOLUME (IN LITERS): 0.1

\section{DECORATION (INCLUDING MOTIF AND}

ELEMENTS WHEN APPARENT): The vessel rim and body is divided into eight panels by vertical excised bracket elements. Within the panels are small excised panels, semi-circles, and narrow curvilinear hatched zones; one semi-circle element has a single hatched pendant spur (Figure 6b)

PIGMENT USE AND LOCATION ON VESSEL: none

TYPE AND VARIETY (IF KNOWN): Poynor Engraved, var. Lang

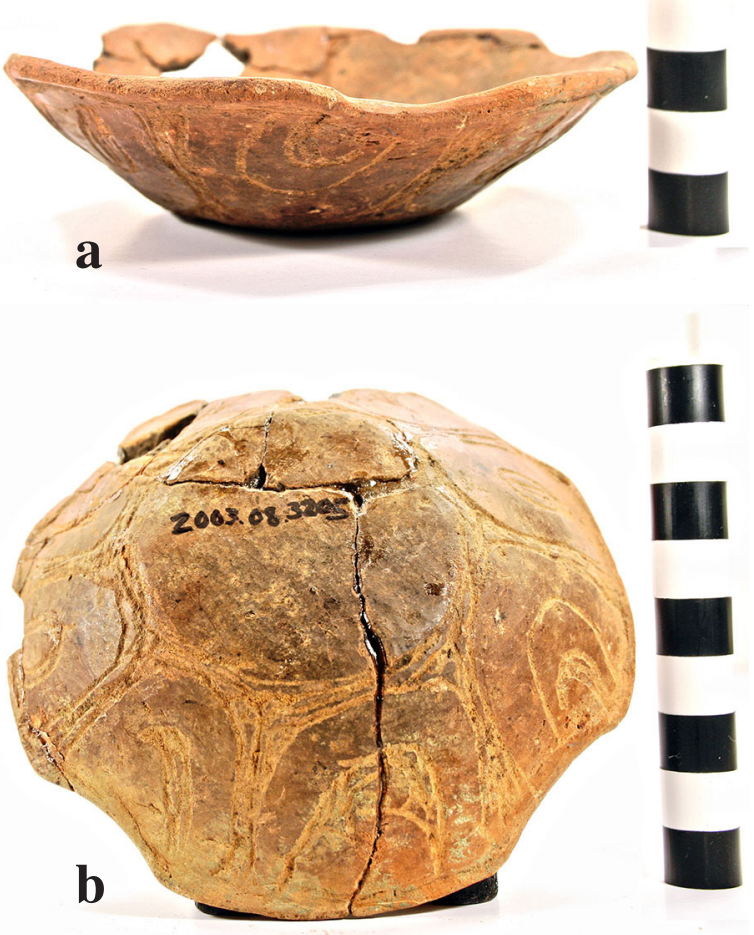

Figure 6. Poynor Engraved, var. Lang bowl from the Pipe site: side view, showing rim peaks; $b$, exterior view of engraved motifs. 
SITE NAME OR SITE NUMBER: Pipe site

VESSEL NO.: 2003.08.3206

VESSEL FORM: Carinated bowl with scalloped lip (Figure 7a)

NON-PLASTICS AND PASTE: grog

RIM AND LIP FORM: Direct rim and rounded, exterior folded lip

CORE COLOR: $\mathrm{F}$ (fired in a reducing environment and cooled in the open air)

INTERIOR SURFACE COLOR: reddish-brown; fire clouds on the rim

EXTERIOR SURFACE COLOR: reddish-brown

WALL THICKNESS (IN MM): rim, $8.6 \mathrm{~mm}$

INTERIOR SURFACE TREATMENT:

smoothed

EXTERIOR SURFACE TREATMENT:

burnished

HEIGHT (IN CM): 8.9

ORIFICE DIAMETER (IN CM): 18.6

DIAMETER AT BOTTOM OF RIM OR NECK (IN CM): 18.5

BASE DIAMETER (IN CM) AND SHAPE OF BASE: $7.6 \mathrm{~cm}$, circular and flat

ESTIMATED VOLUME (IN LITERS): 1.0

DECORATION (INCLUDING MOTIF AND ELEMENTS WHEN APPARENT): The rim panel has four sets of slanted scroll elements with upper and lower scroll fill zones. The triangular-shaped scroll fill zones have excised triangles and short diagonal engraved lines. The sets of scrolls are divided by single vertical engraved lines (Figure 7b).

PIGMENT USE AND LOCATION ON

VESSEL: none

TYPE AND VARIETY (IF KNOWN): Poynor Engraved, var. I (see Perttula 2011a:Figure 6-66)

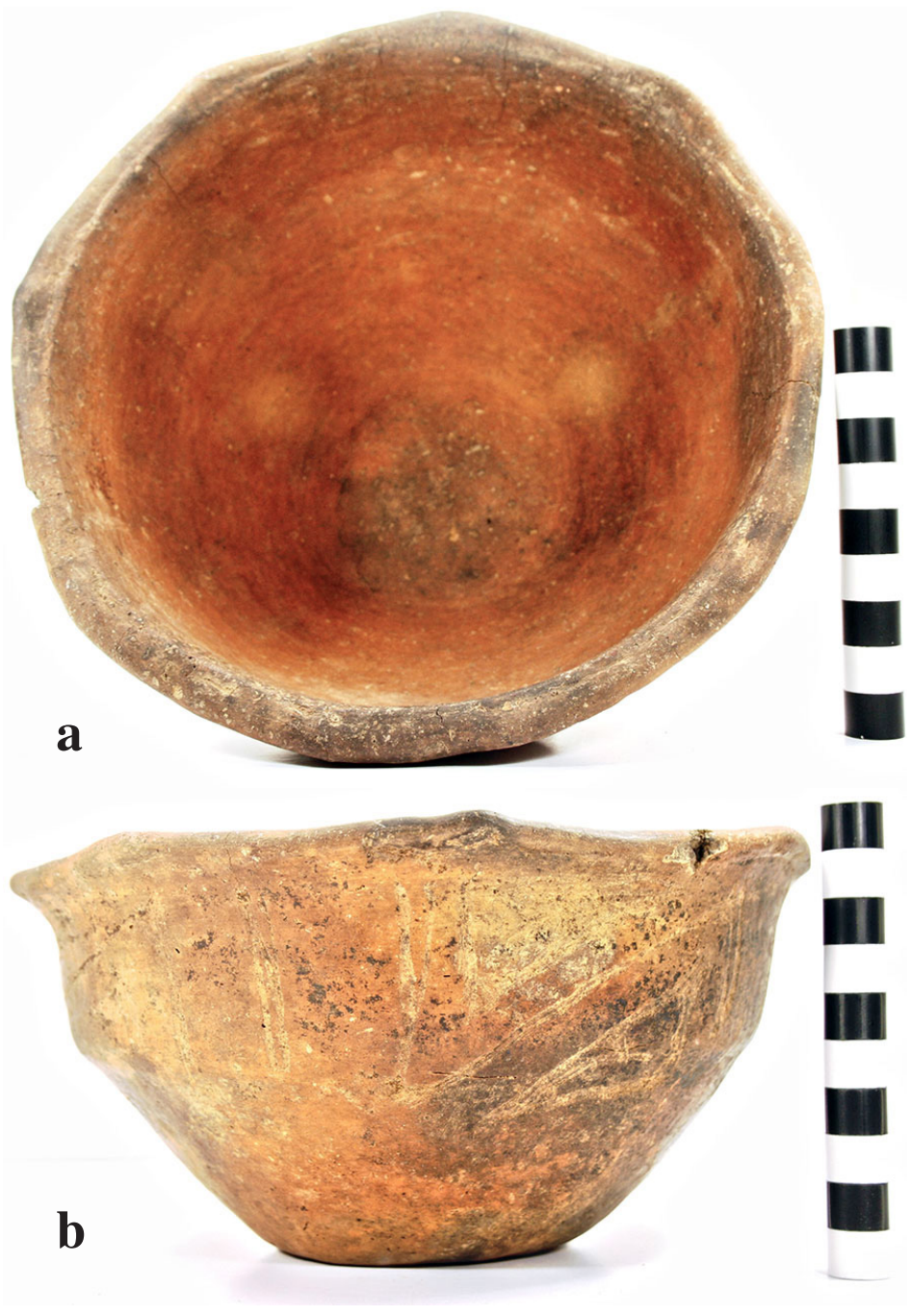

Figure 7. Poynor Engraved, var. I carinated bowl from the Pipe site: a, view of scalloped lip; b, exterior view of engraved motif. 
SITE NAME OR SITE NUMBER: Pipe site

VESSEL NO.: 2003.08.3207

VESSEL FORM: Carinated bowl with scalloped lip

NON-PLASTICS AND PASTE: grog

RIM AND LIP FORM: Direct rim and rounded, exterior folded, lip

CORE COLOR: $\mathrm{F}$ (fired in a reducing environment and cooled in the open air)

INTERIOR SURFACE COLOR: brown

EXTERIOR SURFACE COLOR: reddish-brown

WALL THICKNESS (IN MM): rim, $7.4 \mathrm{~mm}$

INTERIOR SURFACE TREATMENT: smoothed

EXTERIOR SURFACE TREATMENT: burnished

HEIGHT (IN CM): 15.0

ORIFICE DIAMETER (IN CM): 28.8

DIAMETER AT BOTTOM OF RIM OR NECK (IN CM): 28.8

BASE DIAMETER (IN CM) AND SHAPE OF BASE: $10.4 \mathrm{~cm}$, circular and flat

ESTIMATED VOLUME (IN LITERS): 3.9

DECORATION (INCLUDING

MOTIF AND ELEMENTS

WHEN APPARENT): The rim is divided into four panels by sets of vertical engraved lines. Within the panels are slanted scroll lines with triangularshaped upper and lower scroll fill zones (Figure 8). The scroll fill zones have negative oval or S-shaped elements.

\section{PIGMENT USE AND} LOCATION ON VESSEL: none

TYPE AND VARIETY (IF KNOWN): Poynor Engraved, var. unspecified

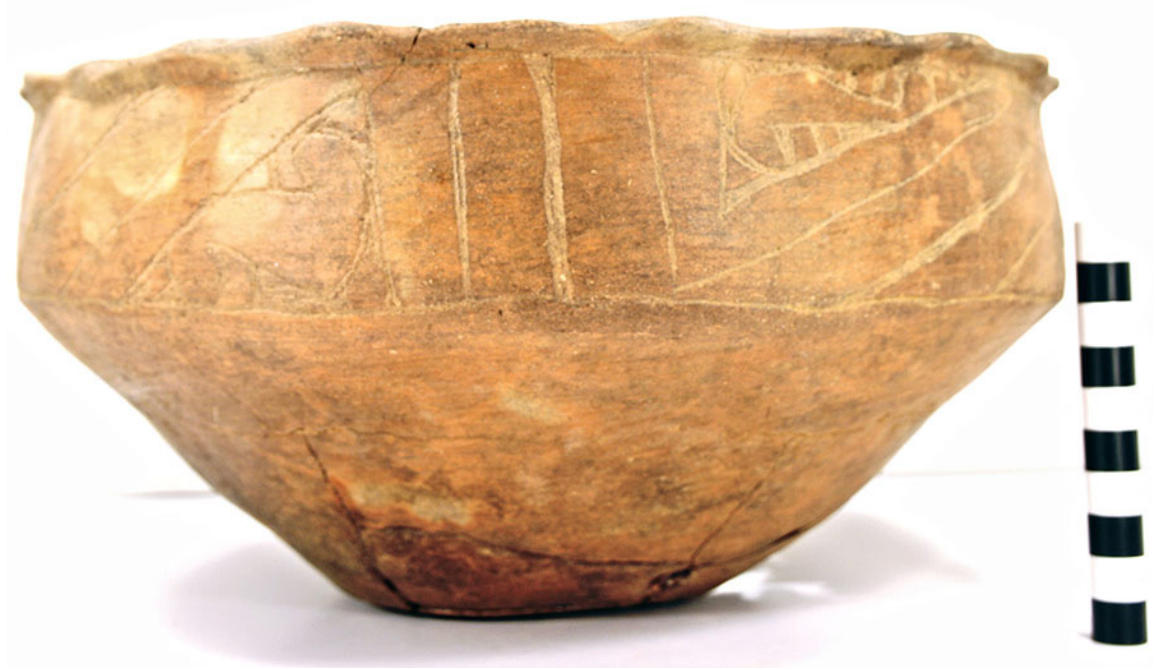

Figure 8. Poynor Engraved, var. unspecified carinated bowl from the Pipe site. 
SITE NAME OR SITE NUMBER: Pipe site

VESSEL NO.: 2003.08.3208

VESSEL FORM: Carinated bowl

NON-PLASTICS AND PASTE: grog and hematite

RIM AND LIP FORM: Direct rim and rounded lip

CORE COLOR: $\mathrm{F}$ (fired in a reducing environment and cooled in the open air)

INTERIOR SURFACE COLOR: yellowish-brown; fire clouds on the rim

EXTERIOR SURFACE COLOR: yellowish-brown; fire clouds on the rim, body, and base

WALL THICKNESS (IN MM): rim, 6.9 mm

INTERIOR SURFACE TREATMENT: smoothed

EXTERIOR SURFACE TREATMENT: smoothed

HEIGHT (IN CM): 11.4

ORIFICE DIAMETER (IN CM): 12.8

DIAMETER AT BOTTOM OF RIM OR NECK (IN CM): 13.2

BASE DIAMETER (IN CM) AND SHAPE OF BASE: $6.7 \mathrm{~cm}$, circular and flat

ESTIMATED VOLUME (IN LITERS): 0.9

DECORATION (INCLUDING MOTIF AND ELEMENTS WHEN APPARENT): Plain (Figure 9)

PIGMENT USE AND LOCATION ON VESSEL: none

TYPE AND VARIETY (IF KNOWN): Unidentified plain ware

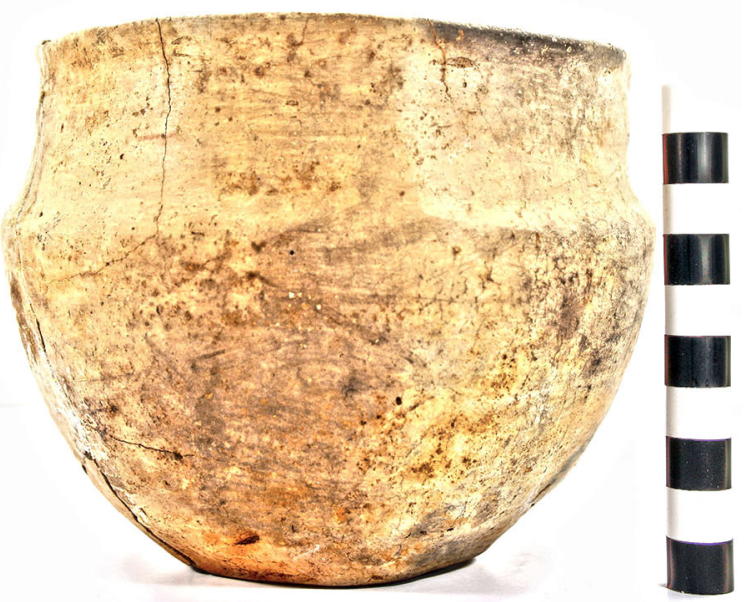

Figure 9. Plain carinated bowl from the Pipe site. 
SITE NAME OR SITE NUMBER: Pipe site

VESSEL NO.: 2003.08.3209

VESSEL FORM: Globular carinated bowl

NON-PLASTICS AND PASTE: grog

RIM AND LIP FORM: Everted rim and rounded lip

CORE COLOR: $\mathrm{F}$ (fired in a reducing environment and cooled in the open air)

INTERIOR SURFACE COLOR: yellowish-brown; fire clouds on the body and base

EXTERIOR SURFACE COLOR: yellowish-brown; fire clouds on the rim, body, and base

WALL THICKNESS (IN MM): rim, $5.2 \mathrm{~mm}$

INTERIOR SURFACE TREATMENT: smoothed

EXTERIOR SURFACE TREATMENT: burnished

HEIGHT (IN CM): 10.8

ORIFICE DIAMETER (IN CM): 15.4

DIAMETER AT BOTTOM OF RIM OR NECK (IN CM): 15.0

BASE DIAMETER (IN CM) AND SHAPE OF BASE: $8.3 \mathrm{~cm}$, circular and rounded

ESTIMATED VOLUME (IN LITERS): 1.0

DECORATION (INCLUDING MOTIF AND ELEMENTS WHEN APPARENT): The rim panel has four sets of slanting scroll elements and upper and lower scroll fill zones that are divided by broad excised bracket elements (Figure 10). The scroll fill zones have excised brackets and triangle elements as well as circle elements with a central excised dot.

PIGMENT USE AND LOCATION ON VESSEL: none

TYPE AND VARIETY (IF KNOWN): Poynor Engraved, var. unspecified

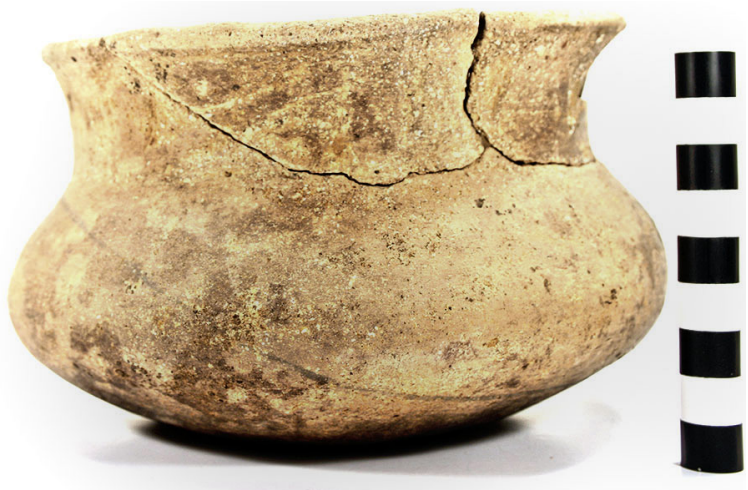

Figure 10. Poynor Engraved, var. unspecified carinated bowl from the Pipe site. 
SITE NAME OR SITE NUMBER: Pipe site

VESSEL NO.: 2003.08.3227

VESSEL FORM: Globular carinated bowl

NON-PLASTICS AND PASTE: grog and bone

RIM AND LIP FORM: Direct rim and rounded lip

CORE COLOR: $\mathrm{F}$ (fired in a reducing environment and cooled in the open air)

INTERIOR SURFACE COLOR: reddish-brown

EXTERIOR SURFACE COLOR: reddish-brown; fire clouds on the body and base

WALL THICKNESS (IN MM): rim, $7.7 \mathrm{~mm}$

INTERIOR SURFACE TREATMENT: smoothed

EXTERIOR SURFACE TREATMENT: burnished

HEIGHT (IN CM): 13.9

ORIFICE DIAMETER (IN CM): 18.7

DIAMETER AT BOTTOM OF RIM OR NECK (IN CM): 18.5

BASE DIAMETER (IN CM) AND SHAPE OF BASE: $11.0 \mathrm{~cm}$, circular and flat

ESTIMATED VOLUME (IN LITERS): 2.3

DECORATION (INCLUDING

MOTIF AND ELEMENTS WHEN

APPARENT): The rim panel is divided into eight oval-shaped areas by vertical hatched brackets. There are single horizontal engraved lines under the vessel lip and at the carination (Figure 11).

PIGMENT USE AND LOCATION ON VESSEL: none

TYPE AND VARIETY (IF KNOWN): Poynor Engraved, var. Cook

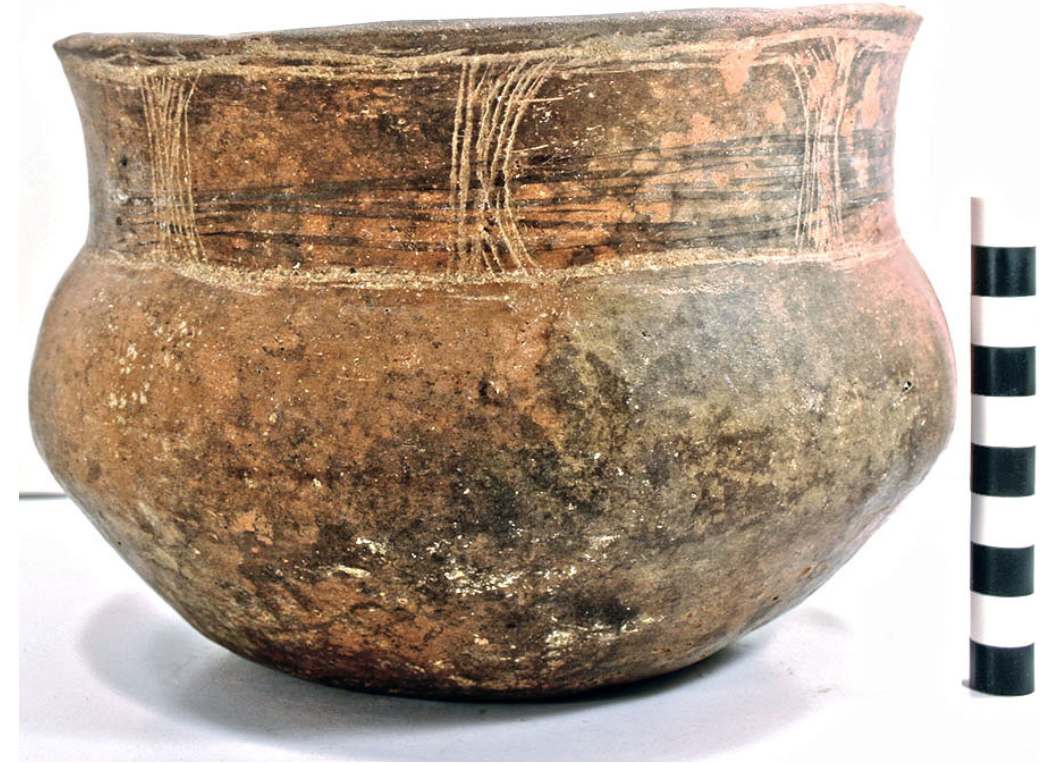

Figure 11. Poynor Engraved, var. Cook carinated bowl from the Pipe site. 
SITE NAME OR SITE NUMBER: Pipe site

VESSEL NO.: 2003.08.3240

VESSEL FORM: Jar

NON-PLASTICS AND PASTE: grog

RIM AND LIP FORM: Direct rim and rounded lip

CORE COLOR: $\mathrm{F}$ (fired in a reducing environment and cooled in the open air)

INTERIOR SURFACE COLOR: yellowish-brown; fire clouds on the rim, body, and base

EXTERIOR SURFACE COLOR: yellowish-brown; fire clouds on the rim and body

WALL THICKNESS (IN MM): rim, $5.8 \mathrm{~mm}$

INTERIOR SURFACE TREATMENT: smoothed

EXTERIOR SURFACE TREATMENT: smoothed on the body

HEIGHT (IN CM): 10.6

ORIFICE DIAMETER (IN CM): 9.6

DIAMETER AT BOTTOM OF RIM OR NECK (IN CM): 9.6

BASE DIAMETER (IN CM) AND SHAPE OF BASE: 7.6 $\mathrm{cm}$, circular and flat

ESTIMATED VOLUME (IN LITERS): 0.6

DECORATION (INCLUDING MOTIF AND ELEMENTS

WHEN APPARENT): Diagonal incised lines on the rim panel, drawn from left to right (Figure 12).

PIGMENT USE AND LOCATION ON VESSEL: none

TYPE AND VARIETY (IF KNOWN): Maydelle Incised

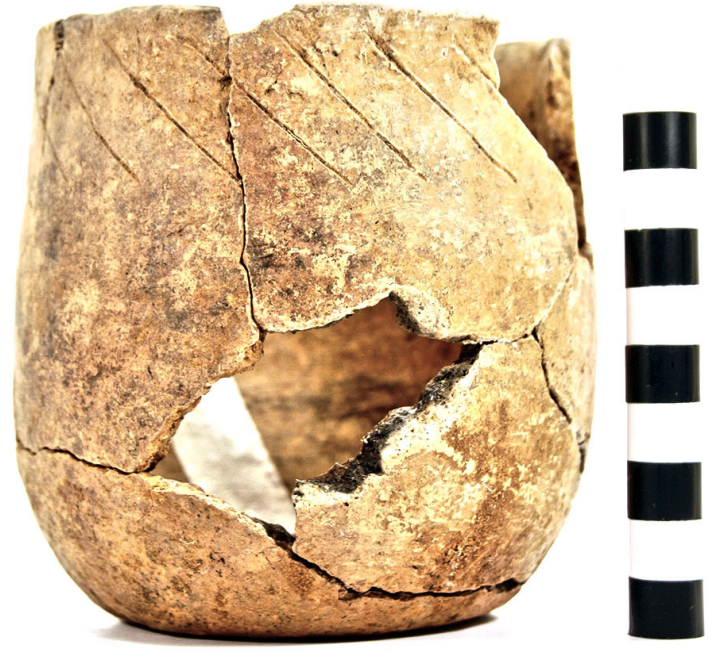

Figure 12. Maydelle Incised jar from the Pipe site.

SITE NAME OR SITE NUMBER: Pipe site

VESSEL NO.: 2003.08.3241

VESSEL FORM: Effigy bowl with broken bird effigy head (55 x $14 \mathrm{~mm}$ in length and width) and tab tail (63 x $26 \mathrm{~mm}$ in length and width) (Figure 13)

NON-PLASTICS AND PASTE: grog

RIM AND LIP FORM: Direct rim and flat lip 
CORE COLOR: $\mathrm{F}$ (fired in a reducing environment and cooled in the open air)

INTERIOR SURFACE COLOR: yellowish-brown; fire clouds on the bird effigy head and tab tail

EXTERIOR SURFACE COLOR: brown; fire clouds on the rim and body

WALL THICKNESS (IN MM): rim, $5.0 \mathrm{~mm}$

INTERIOR SURFACE TREATMENT: burnished

EXTERIOR SURFACE TREATMENT: burnished

HEIGHT (IN CM): 10.6

ORIFICE DIAMETER (IN CM): 16.8

DIAMETER AT BOTTOM OF RIM OR NECK (IN CM): N/A

BASE DIAMETER (IN CM) AND SHAPE OF BASE: $9.8 \mathrm{~cm}$, circular and flat

ESTIMATED VOLUME (IN LITERS): 0.7

DECORATION

(INCLUDING MOTIF

AND ELEMENTS WHEN

APPARENT): The rim and body of the vessel have four horizontal engraved lines (Figure 13); the lines do not dip below the effigy head or the tab tail.

PIGMENT USE AND LOCATION ON VESSEL: red pigment in the engraved lines

TYPE AND VARIETY (IF KNOWN): Hood Engraved, var. Hood

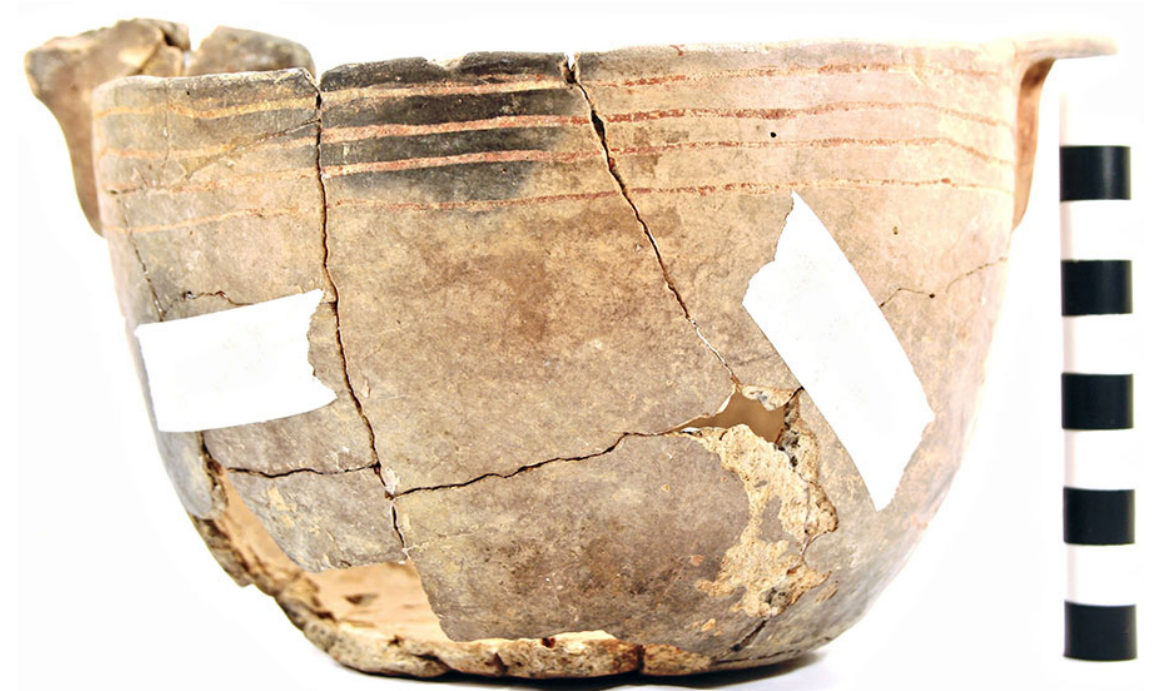

Figure 13. Hood Engraved, var. Hood effigy bowl from the Pipe site.

\section{Mud Creek or Damon Ramey Site, Cherokee County, Texas}

Perttula and Nelson (2013a) previously documented four vessels in the Buddy Jones collection from the Mud Creek site, also known as the Damon Ramey site; it has not been formally recorded and does not have a state trinomial. This site is near Reklaw, Texas, by U.S. 84 where it crosses Mud Creek, a major southward-flowing tributary to the Angelina River. Bill Young had told the senior author several years ago about a Caddo cemetery at this approximate location on Mud Creek. According to Jones, a total of five burials were excavated here, although it is not known if all five burials were excavated by Jones or other unknown individuals. The four vessels documented from the site are from Burials 3 and 4 . The vessels were grog-tempered fine wares from several different varieties of Poynor Engraved, a local fine ware of the Frankston phase (ca. A.D. 1400-1680) in the Neches-Angelina River basins. These different 
varieties, including cf. var. Blackburn, var. Hood, and regional variety Var. L suggested that the Caddo cemetery was in use sometime between ca. A.D. 1400-1560 (Perttula 2011a:Table 6-37).

SITE NAME OR SITE NUMBER: Mud Creek or Damon Ramey site

VESSEL NO.: 2003.08.3211

VESSEL FORM: Effigy bowl with a bird head effigy (46 x $34 \mathrm{~mm}$ in height and width) and tab tail (44 x $24 \mathrm{~mm}$ in length and width) (Figure 14)

NON-PLASTICS AND PASTE: grog

RIM AND LIP FORM: Direct rim and rounded lip

CORE COLOR: A (fired and cooled in an oxidizing environment)

INTERIOR SURFACE COLOR: brown; fire clouds on the rim and body

EXTERIOR SURFACE COLOR: brown; fire clouds on the rim, body, and base, as well as on the effigy head and tab tail

WALL THICKNESS (IN MM): rim, $5.0 \mathrm{~mm}$

INTERIOR SURFACE TREATMENT: burnished

EXTERIOR SURFACE TREATMENT: burnished

HEIGHT (IN CM): $7.4 \mathrm{~cm} ; 9.5 \mathrm{~cm}$ in height at the top of the effigy head

ORIFICE DIAMETER (IN CM): $16.0 \mathrm{~cm}$

DIAMETER AT BOTTOM OF RIM OR NECK (IN CM): N/A

BASE DIAMETER (IN CM) AND SHAPE OF BASE: $9.5 \mathrm{~cm}$, circular and flat

ESTIMATED VOLUME (IN LITERS): 0.5

\section{DECORATION (INCLUDING MOTIF AND}

ELEMENTS WHEN APPARENT): The vessel has three broadly-spaced horizontal engraved lines. The bird effigy head, which points towards the tab tail, has two concentric engraved circles, while the tab tail has two concentric engraved semi-circles (Figure 14).

\section{PIGMENT USE AND LOCATION ON VESSEL:} none

TYPE AND VARIETY (IF KNOWN): Hood Engraved, var. Mud Creek

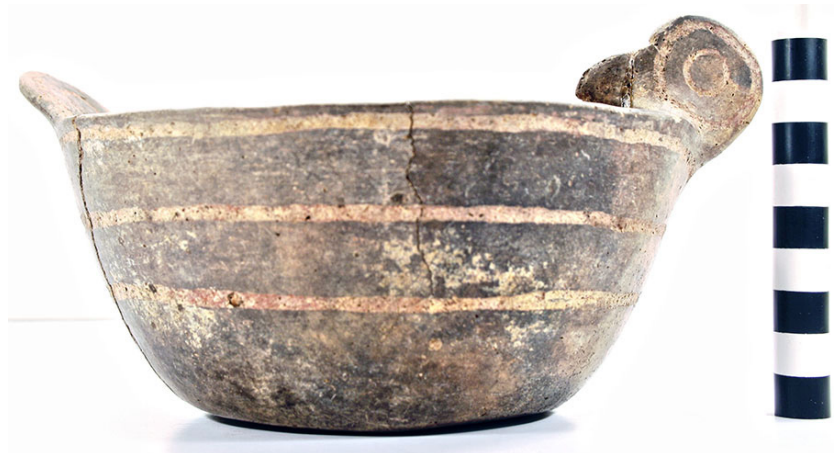

Figure 14. Hood Engraved, var. Mud Creek effigy bowl from the Mud Creek site. 
SITE NAME OR SITE NUMBER: Mud Creek or Damon Ramey site

VESSEL NO.: 2003.08.3212

VESSEL FORM: Effigy bowl with bird effigy head (58 x $47 \mathrm{~mm}$ in length and height) and tab tail (72 $\mathrm{x}$ $38 \mathrm{~mm}$ in length and width) (Figure 15)

NON-PLASTICS AND PASTE: grog

RIM AND LIP FORM: Direct rim and flat lip

CORE COLOR: $\mathrm{F}$ (fired in a reducing environment and cooled in the open air)

INTERIOR SURFACE COLOR: yellowish-brown

EXTERIOR SURFACE COLOR: yellowish-brown; fire clouds on the rim, body, and base

WALL THICKNESS (IN MM): rim, $5.3 \mathrm{~mm}$

INTERIOR SURFACE TREATMENT: smoothed

EXTERIOR SURFACE TREATMENT: burnished

HEIGHT (IN CM): $10.0 \mathrm{~cm}$

ORIFICE DIAMETER (IN CM): $21.0 \mathrm{~cm}$

DIAMETER AT BOTTOM OF RIM OR NECK (IN CM): N/A

BASE DIAMETER (IN CM) AND SHAPE OF BASE: $11.4 \mathrm{~cm}$, circular and flat

ESTIMATED VOLUME (IN LITERS): 0.8

DECORATION (INCLUDING

MOTIF AND ELEMENTS WHEN

APPARENT): Three widely-spaced horizontal engraved lines on the rim and body. The bird effigy head has engraved concentric circles around a central circle or eye, and the beak has an engraved mouth line. The tab tail has large engraved triangle elements that fit the tab tail (Figure 15).

PIGMENT USE AND LOCATION ON VESSEL: none

TYPE AND VARIETY (IF KNOWN): Hood Engraved, var. Mud Creek

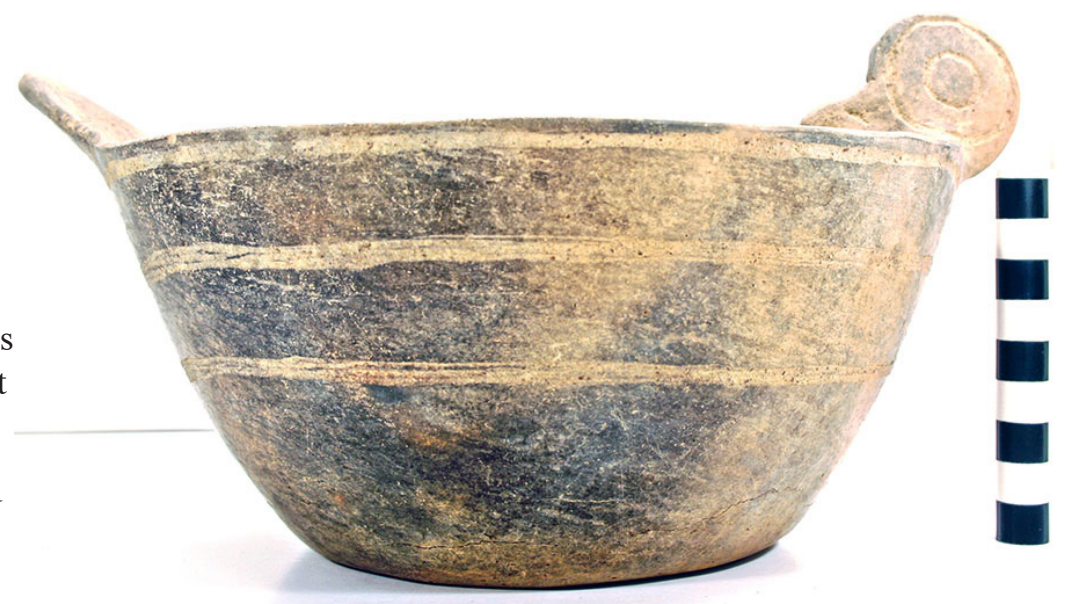

Figure 15. Hood Engraved, var. Mud Creek effigy bowl from the Mud Creek site. 
SITE NAME OR SITE NUMBER: Mud Creek or Damon Ramey site

VESSEL NO.: 2003.08.3213

VESSEL FORM: Effigy bowl with broken bird effigy head $(39.0 \mathrm{~mm}$ in height and $9 \mathrm{~mm}$ in width) and tab tail (48 x $12 \mathrm{~mm}$ in length and width) (Figure 16)

NON-PLASTICS AND PASTE: grog

RIM AND LIP FORM: Direct rim and flat lip

CORE COLOR: $\mathrm{F}$ (fired in a reducing environment and cooled in the open air)

INTERIOR SURFACE COLOR: red

EXTERIOR SURFACE COLOR: red

WALL THICKNESS (IN MM): rim, $5.0 \mathrm{~mm}$

INTERIOR SURFACE TREATMENT: burnished

EXTERIOR SURFACE TREATMENT: burnished; fire clouds on the rim, body, and base

HEIGHT (IN CM): 4.6

ORIFICE DIAMETER (IN CM): 8.9

DIAMETER AT BOTTOM OF RIM OR NECK (IN CM): N/A

BASE DIAMETER (IN CM) AND SHAPE OF BASE: $5.6 \mathrm{~cm}$, circular and flat

ESTIMATED VOLUME (IN LITERS): 0.2

DECORATION (INCLUDING MOTIF AND ELEMENTS WHEN APPARENT): There are three widely-spaced horizontal engraved lines on the rim and body (Figure 16). Both vessel surfaces have a hematite-rich clay slip.

PIGMENT USE AND LOCATION ON VESSEL: none

TYPE AND VARIETY (IF KNOWN): Hood Engraved, var. Hood

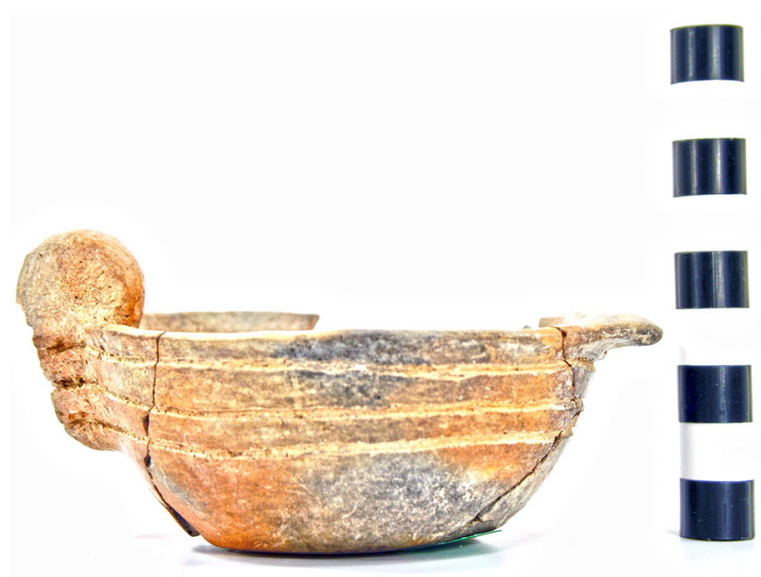

Figure 16. Hood Engraved, var. Hood effigy bowl from the Mud Creek site. 
SITE NAME OR SITE NUMBER: Mud Creek or Damon Ramey site

VESSEL NO.: 2003.08.3214, Burial 3, Excavated February 1968

VESSEL FORM: Carinated bowl with a scalloped lip

NON-PLASTICS AND PASTE: grog

RIM AND LIP FORM: Direct rim and rounded, exterior folded lip

CORE COLOR: $\mathrm{F}$ (fired in a reducing environment and cooled in the open air)

INTERIOR SURFACE COLOR: yellowish-brown

EXTERIOR SURFACE COLOR: yellowish-brown; fire clouds on the rim, body, and base

WALL THICKNESS (IN MM): rim, $4.3 \mathrm{~mm}$; body, $5.3 \mathrm{~mm}$; base, $7.1 \mathrm{~mm}$

INTERIOR SURFACE TREATMENT: smoothed

EXTERIOR SURFACE TREATMENT: burnished

HEIGHT (IN CM): 6.4

ORIFICE DIAMETER (IN CM): 16.8

DIAMETER AT BOTTOM OF RIM OR NECK (IN CM): 16.6

BASE DIAMETER (IN CM) AND SHAPE OF BASE: $7.2 \mathrm{~cm}$, circular and flat

ESTIMATED VOLUME (IN LITERS): 0.6

DECORATION (INCLUDING MOTIF AND ELEMENTS WHEN APPARENT): The rim panel has a series of crosshatched brackets, slanted scroll lines, and upper and lower scroll fill zones with cross-hatched triangle elements (Figure 17).

PIGMENT USE AND LOCATION ON VESSEL: none

TYPE AND VARIETY (IF KNOWN): Unidentified fine ware

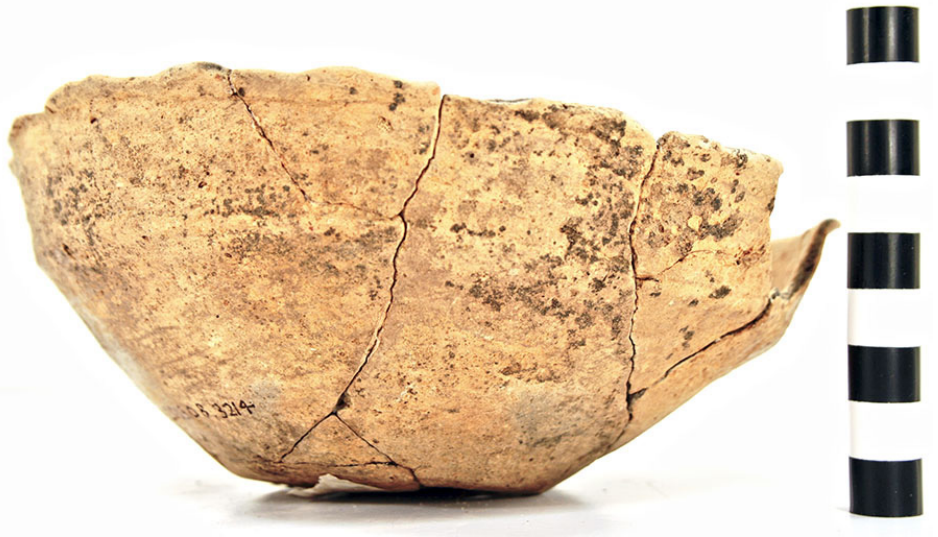

Figure 17. Engraved carinated bowl from the Mud Creek site. 


\section{H. C. Slider Site, Cherokee County, Texas}

The H. C. Slider site is a Late Caddo habitation site and cemetery in the Neches River valley in western Cherokee County, in the East Texas Pineywoods (Perttula and Nelson 2013b). The site was found and investigated by Buddy Calvin Jones in November and December 1967.

According to Jones' notes, the site is on three sandy knolls along a Neches River terrace, approximately 11 miles southwest of the city of Jacksonville. These knolls (A-C) have midden deposits with ceramic sherds and lithic artifacts. Knoll A has a cemetery, and Jones excavated four burials (Burials 1-4) at the northern end of the knoll. The four burials excavated by Jones at the H. C. Slider site were dispersed across a ca. $10 \mathrm{~m}$ long area at the northwestern edge of the Area A knoll (see Perttula and Nelson 2013b:Figure 4). The burial pits were oriented northwest-southeast, with single individuals interred in an extended position, with their heads apparently at the southeastern end of the pits, facing to the northwest. Each of the burials contains ceramic vessels as associated funerary offerings.

The ceramic vessels previously documented by Perttula and Nelson (2013b) included fine wares $(n=4)$, utility wares $(n=5)$, and plain wares $(n=4)$. Among the fine wares were a Hood Engraved, var. Hood effigy bowl, one Poynor Engraved, Var. A carinated bowl, and two cylindrical Poynor Engraved bottles with short necks, while the utility wares included three Killough Pinched jars (one with a pedestal base), a diagonal incised jar (possibly Maydelle Incised), and a Bullard Brushed jar. The plain wares are globular-shaped $(n=2)$ and simple $(n=2)$ carinated bowls of several sizes. The decorated vessels, and the distinctive vessel forms, from the burials are stylistically consistent with a Frankston phase component in the upper Neches River valley. The occurrence of the one Var. A Poynor Engraved vessel and the Hood Engraved, var. Hood effigy vessel at the site suggests that the burials date from the early part of the Frankston phase, from ca. A.D. 1400-1480 (see Perttula 2011a:Table 6-37).

SITE NAME OR SITE NUMBER: H. C. Slider

VESSEL NO.: 2003.08.3217, Burial 2, Vessel \#4

VESSEL FORM: Short-necked bottle

NON-PLASTICS AND PASTE: grog and sandy paste

RIM AND LIP FORM: Direct rim and flat lip

CORE COLOR: $\mathrm{G}$ (fired in a reducing environment and cooled in the open air)

INTERIOR SURFACE COLOR: dark grayish-brown

EXTERIOR SURFACE COLOR: reddish-brown to yellowish-brown; fire clouds on the body and neck

WALL THICKNESS (IN MM): rim, $5.1 \mathrm{~mm}$

INTERIOR SURFACE TREATMENT: none

EXTERIOR SURFACE TREATMENT: burnished

HEIGHT (IN CM): 22.6

ORIFICE DIAMETER (IN CM): 4.4 
DIAMETER AT BOTTOM OF RIM OR NECK (IN CM): 4.4; maximum body diameter of $11.1 \mathrm{~cm}$

BASE DIAMETER (IN CM) AND SHAPE OF BASE: $9.8 \mathrm{~cm}$; circular and flat

ESTIMATED VOLUME (IN LITERS): 1.0

DECORATION (INCLUDING MOTIF AND ELEMENTS WHEN APPARENT): The vessel body has two sets of closely-spaced vertical engraved lines with hatched pendant triangles that alternate with two sets of five vertical engraved lines and a central area of four concentric circles (Figure 18a-b). There are two horizontal engraved lines at the base of the vertical engraved elements.

PIGMENT USE AND LOCATION ON VESSEL: none

TYPE AND VARIETY (IF KNOWN): Hume Engraved, var. unspecified
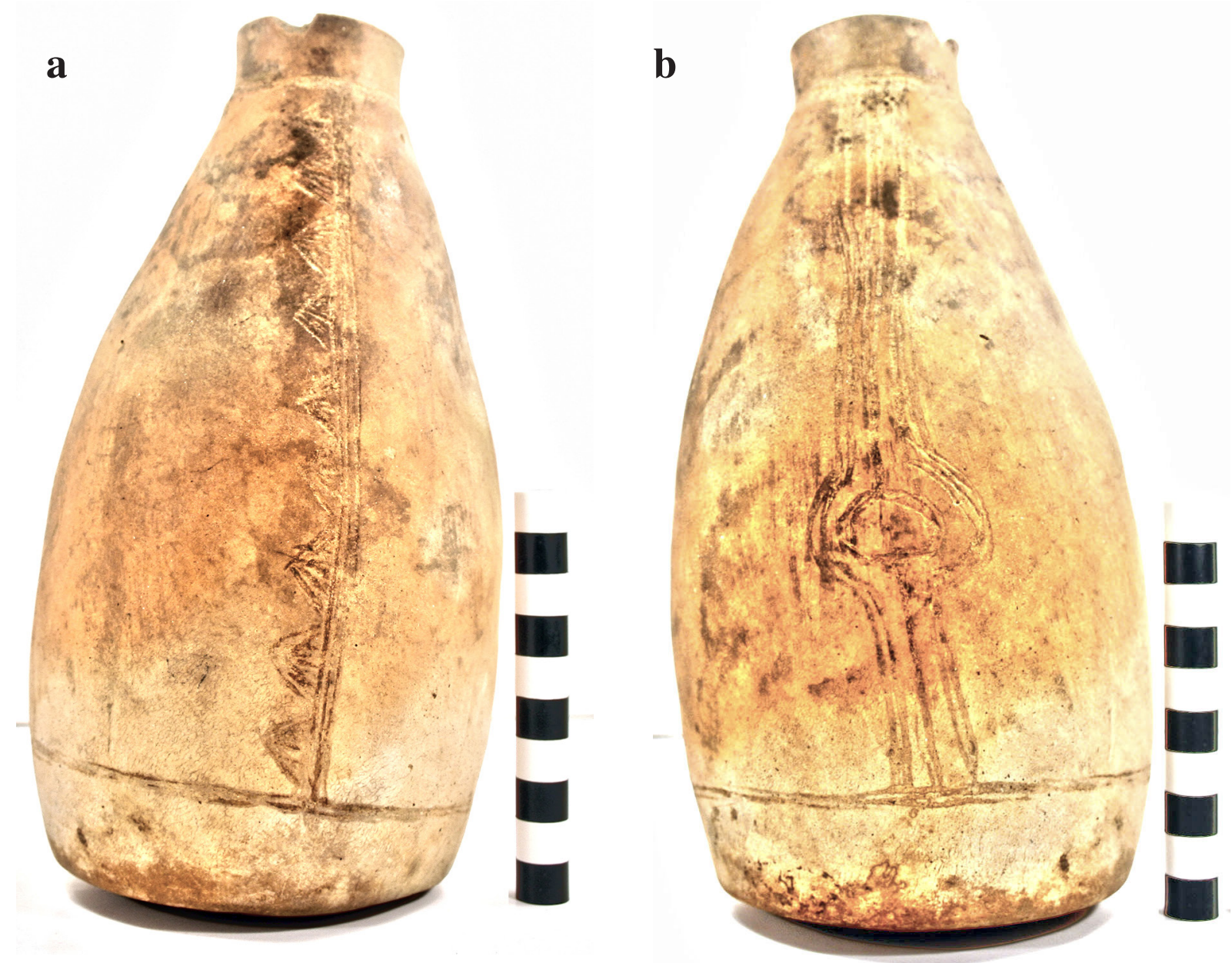

Figure 18. Hume Engraved, var. unspecified bottle from the H. C. Slider site: a, hatched pendant triangle motif; $\mathrm{b}$, concentric circle motif. 
SITE NAME OR SITE NUMBER: H. C. Slider site

VESSEL NO.: 2003.08.3218, Burial 2, Vessel 2

VESSEL FORM: Bottle with a long neck and a carinated body

NON-PLASTICS AND PASTE: grog and hematite

RIM AND LIP FORM: Direct rim and flat lip

$\mathbf{a}$

CORE COLOR: $\mathrm{G}$ (fired in a reducing environment and cooled in the open air)

INTERIOR SURFACE COLOR: dark grayish-brown

EXTERIOR SURFACE COLOR: reddish-brown

WALL THICKNESS (IN MM): rim, $8.3 \mathrm{~mm}$; body, 7.4 $\mathrm{mm}$

INTERIOR SURFACE TREATMENT: none

EXTERIOR SURFACE TREATMENT: burnished

HEIGHT (IN CM): 22.6

ORIFICE DIAMETER (IN CM): 5.3

DIAMETER AT BOTTOM OF RIM OR NECK (IN $\mathrm{CM}$ ): $5.8 \mathrm{~cm}$; maximum body diameter is $18.8 \mathrm{~cm}$

BASE DIAMETER (IN CM) AND SHAPE OF BASE: $8.9 \mathrm{~cm}$, circular and flat

ESTIMATED VOLUME (IN LITERS): 0.8

DECORATION (INCLUDING MOTIF AND ELEMENTS WHEN APPARENT): The vessel body has two panels defined by large vertical crosshatched bracket elements with negative ovals (Figure 19a). The panels each have a set of centrally-placed concentric grooved circles (Figure 19b). There is a single horizontal engraved line at the base of the bottle neck.

PIGMENT USE AND LOCATION ON VESSEL: red pigment in engraved lines

TYPE AND VARIETY (IF KNOWN): Unidentified fine ware

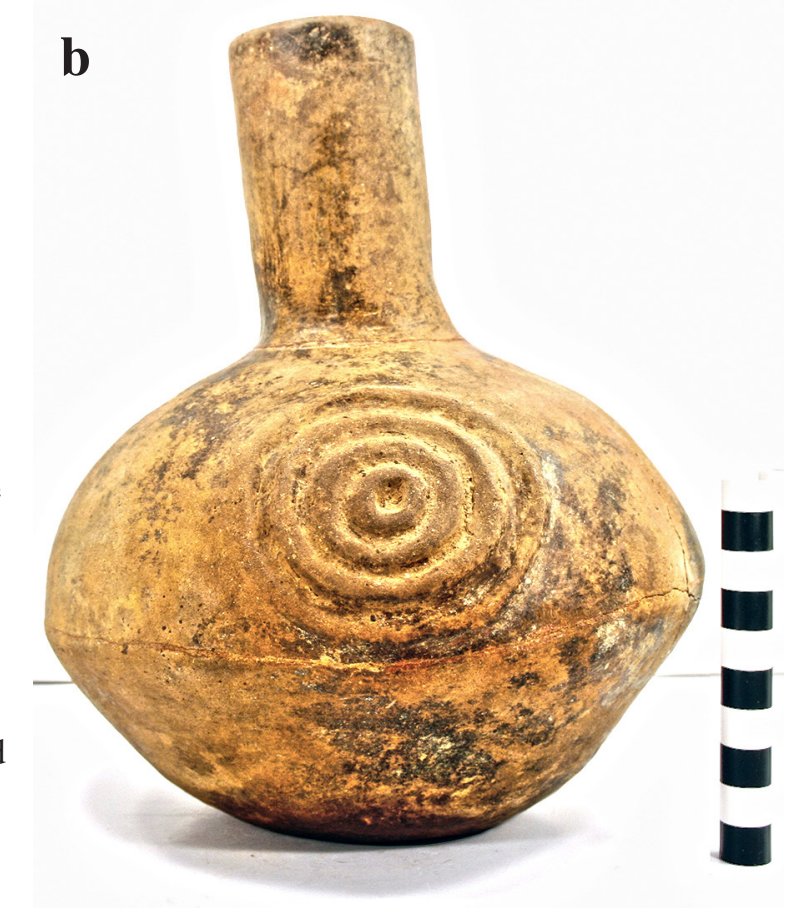

Figure 19. Engraved-grooved bottle from the $\mathrm{H}$. C. Slider site: a, cross-hatched bracket element; b, grooved circles. 
SITE NAME OR SITE NUMBER: H. C. Slider

VESSEL NO.: 2003.08.3219

VESSEL FORM: Bottle with a long neck and a carinated body

NON-PLASTICS AND PASTE: grog and bone RIM AND LIP FORM: Direct rim and rounded lip

CORE COLOR: $\mathrm{G}$ (fired in a reducing environment and cooled in the open air)

INTERIOR SURFACE COLOR: dark grayish-brown

EXTERIOR SURFACE COLOR: brown; fire clouds on the neck and body

WALL THICKNESS (IN MM): rim, $6.3 \mathrm{~mm}$

INTERIOR SURFACE TREATMENT: none

EXTERIOR SURFACE TREATMENT: burnished

HEIGHT (IN CM): 27.8

ORIFICE DIAMETER (IN CM): 4.6

DIAMETER AT BOTTOM OF RIM OR NECK (IN $\mathrm{CM}$ ): $6.9 \mathrm{~cm}$; maximum body diameter is $19.0 \mathrm{~cm}$

BASE DIAMETER (IN CM) AND SHAPE OF BASE: $7.6 \mathrm{~cm}$, circular and flat

ESTIMATED VOLUME (IN LITERS): 0.8

\section{DECORATION (INCLUDING MOTIF AND}

ELEMENTS WHEN APPARENT): The vessel body has two panels defined by four large vertical crosshatched bracket elements with a stacked series of negative ovals (Figure 20a). The panels each have a set of centrally-placed concentric grooved circles (Figure 20b).

PIGMENT USE AND LOCATION ON VESSEL: none

TYPE AND VARIETY (IF KNOWN): Unidentified fine ware a

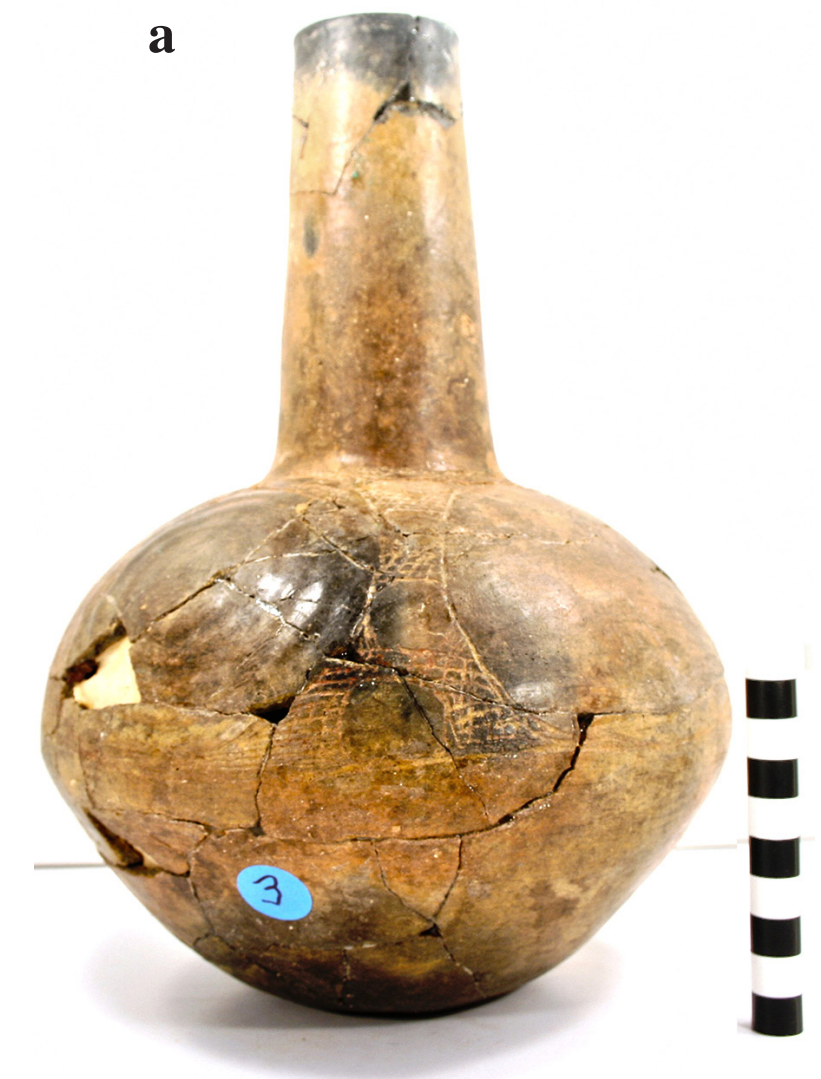

b

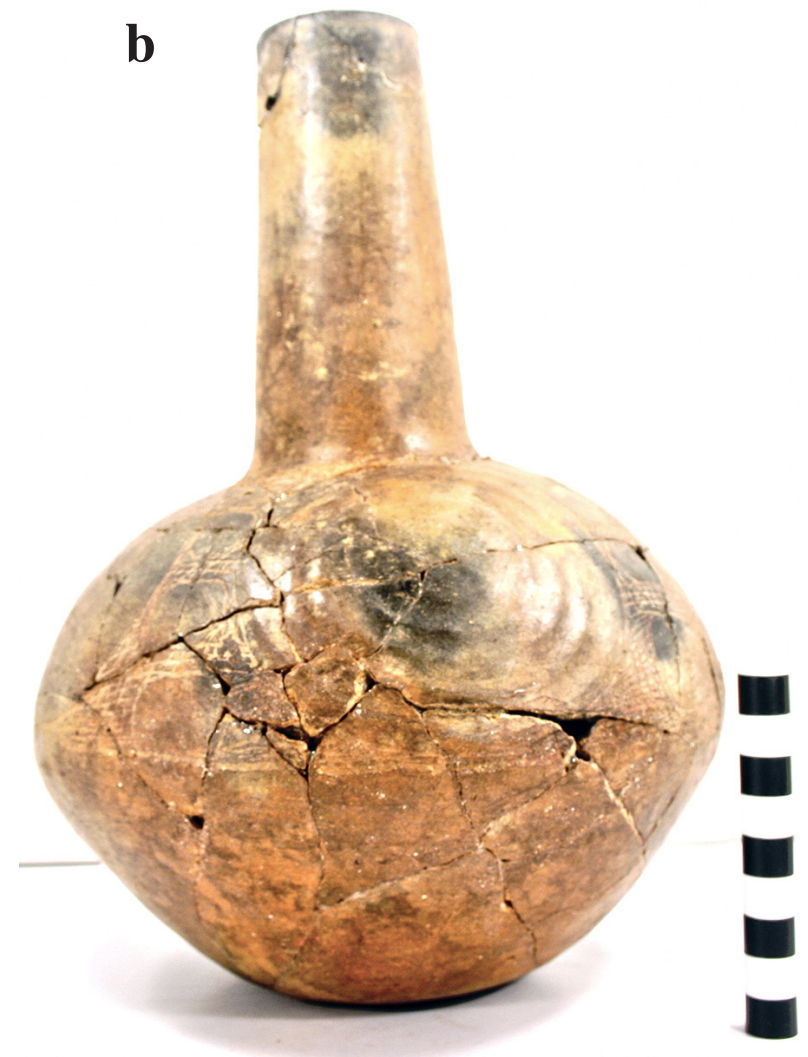

Figure 20. Engraved-grooved bottle from the H. C. Slider site: a, cross-hatched bracket element; b, grooved circle element. 
SITE NAME OR SITE NUMBER: H. C. Slider

VESSEL NO.: 2003.08.3221, Burial 4, \#11

VESSEL FORM: Short-necked bottle

NON-PLASTICS AND PASTE: grog

RIM AND LIP FORM: Everted rim and rounded lip

CORE COLOR: $\mathrm{G}$ (fired in a reducing environment and cooled in the open air)

INTERIOR SURFACE COLOR: dark grayish-brown

EXTERIOR SURFACE COLOR: dark brown

WALL THICKNESS (IN MM): rim, $5.0 \mathrm{~mm}$

INTERIOR SURFACE TREATMENT: none

EXTERIOR SURFACE TREATMENT: burnished

HEIGHT (IN CM): 21.1

ORIFICE DIAMETER (IN CM): 4.5

DIAMETER AT BOTTOM OF RIM OR NECK (IN

$\mathrm{CM}$ ): 4.3 ; maximum body diameter is $13.5 \mathrm{~cm}$

BASE DIAMETER (IN CM) AND SHAPE OF

BASE: $8.9 \mathrm{~cm}$, circular and flat

ESTIMATED VOLUME (IN LITERS): 0.8

\section{DECORATION (INCLUDING MOTIF AND}

ELEMENTS WHEN APPARENT): The upper part of the vessel body has three sets of negative scrolls outlined by upper and lower scroll fill zones. The scroll fill zones have sets of hatched curvilinear engraved lines (Figure 21). The remainder of the vessel body has two sets of single vertical engraved lines with large excised pendant triangles, and two sets of upper and lower stacked excised triangles (Figure 21).

PIGMENT USE AND LOCATION ON VESSEL: red pigment in the engraved lines

TYPE AND VARIETY (IF KNOWN): Hume Engraved, var. unspecified

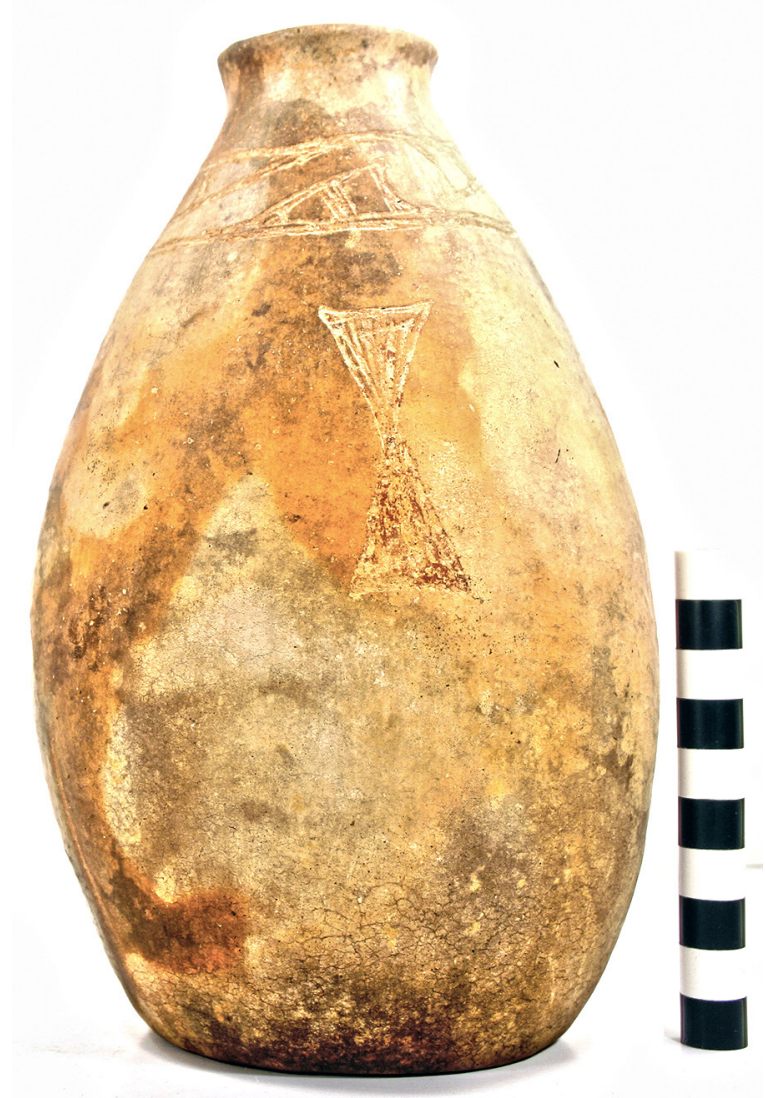

Figure 21. Hume Engraved, var. unspecified short-necked bottle from the H. C. Slider site. 
SITE NAME OR SITE NUMBER: H. C. Slider

VESSEL NO.: 2003.08.3222

VESSEL FORM: Bottle with a short neck

NON-PLASTICS AND PASTE: grog

RIM AND LIP FORM: Direct rim and flat lip

CORE COLOR: B (fired and cooled in a reducing environment)

INTERIOR SURFACE COLOR: dark grayish-brown

EXTERIOR SURFACE COLOR: black; fire clouds on the body

WALL THICKNESS (IN MM): rim, $6.6 \mathrm{~mm}$

INTERIOR SURFACE TREATMENT: none

EXTERIOR SURFACE TREATMENT: burnished

HEIGHT (IN CM): 24.0

ORIFICE DIAMETER (IN CM): 4.5

DIAMETER AT BOTTOM OF RIM OR NECK (IN $\mathrm{CM})$ : 4.5 ; maximum body diameter is $14.2 \mathrm{~cm}$

BASE DIAMETER (IN CM) AND SHAPE OF BASE: $10.2 \mathrm{~cm}$, circular and flat

ESTIMATED VOLUME (IN LITERS): 1.0

DECORATION (INCLUDING MOTIF AND ELEMENTS WHEN APPARENT): The top and bottom of the engraved body panels have three horizontal engraved lines. Between these engraved lines, the four panels are divided into two sets with horizontal and vertical engraved lines and narrow hatched zones, along with upper rectilinear zones with curvilinear and hatched lines, or with lower zones with negative ovals and negative-S elements (Figure 22).

PIGMENT USE AND LOCATION ON VESSEL: red pigment in the engraved lines

TYPE AND VARIETY (IF KNOWN): Poynor Engraved, var. unspecified

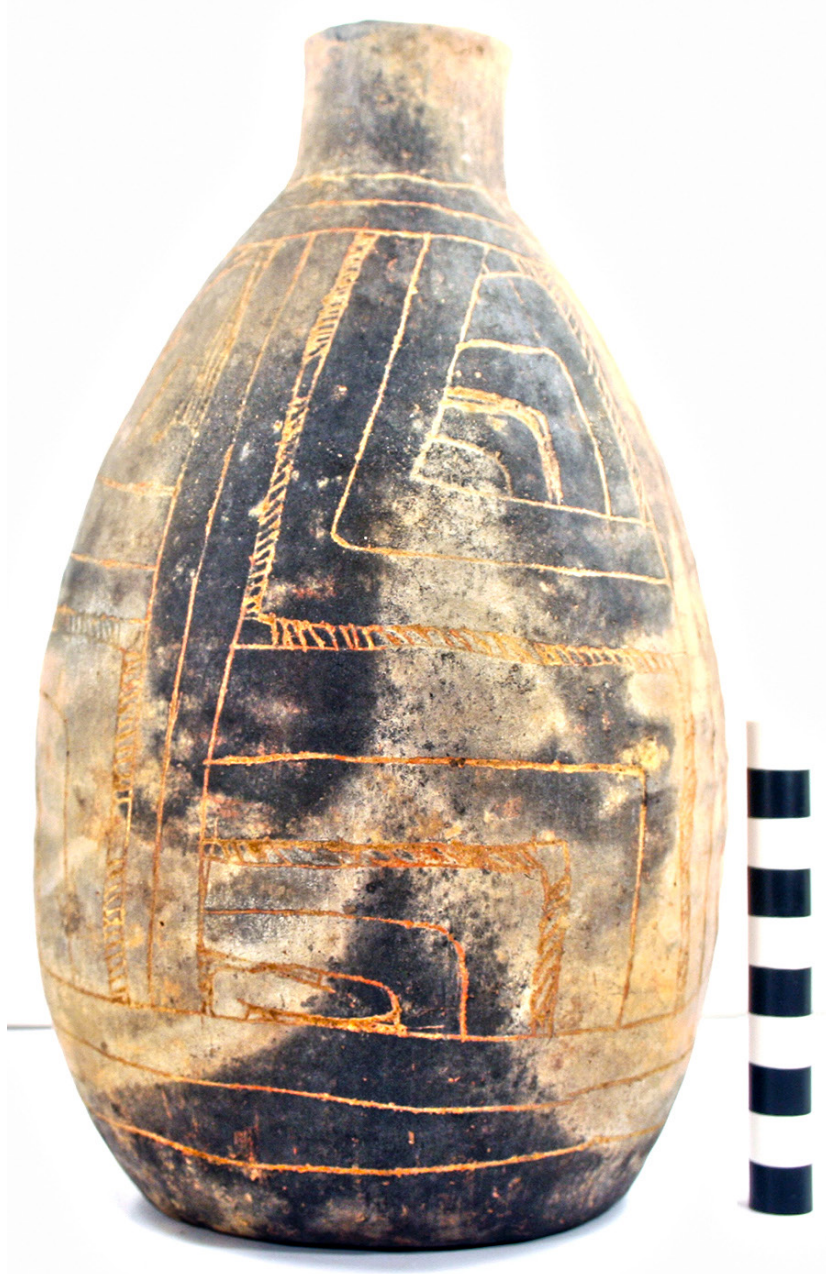

Figure 22. Poynor Engraved, var. unspecified shortnecked bottle from the H. C. Slider site. 
SITE NAME OR SITE NUMBER: H. C. Slider

VESSEL NO.: 2003.08.3237

VESSEL FORM: Globular carinated bowl

NON-PLASTICS AND PASTE: grog and bone

RIM AND LIP FORM: Direct rim and rounded lip

CORE COLOR: $\mathrm{F}$ (fired in a reducing environment and cooled in the open air)

INTERIOR SURFACE COLOR: reddish-brown; fire clouds on the rim

EXTERIOR SURFACE COLOR: reddish-brown; fire clouds on the rim and body

WALL THICKNESS (IN MM): rim, $6.7 \mathrm{~mm}$

INTERIOR SURFACE TREATMENT: burnished

EXTERIOR SURFACE TREATMENT: burnished

HEIGHT (IN CM): 16.3

ORIFICE DIAMETER (IN CM): 20.5

DIAMETER AT BOTTOM OF RIM OR NECK (IN CM): 20.3

BASE DIAMETER (IN CM) AND SHAPE OF BASE: $9.5 \mathrm{~cm}$, circular and flat

ESTIMATED VOLUME (IN LITERS): 3.0

DECORATION (INCLUDING

MOTIF AND ELEMENTS WHEN

APPARENT): The rim panel is divided by four sets of vertically hatched brackets and two sets of wide brackets filled with excised punctations (Figure 23).

PIGMENT USE AND LOCATION ON VESSEL: none

TYPE AND VARIETY (IF KNOWN): Poynor Engraved, var. Hood

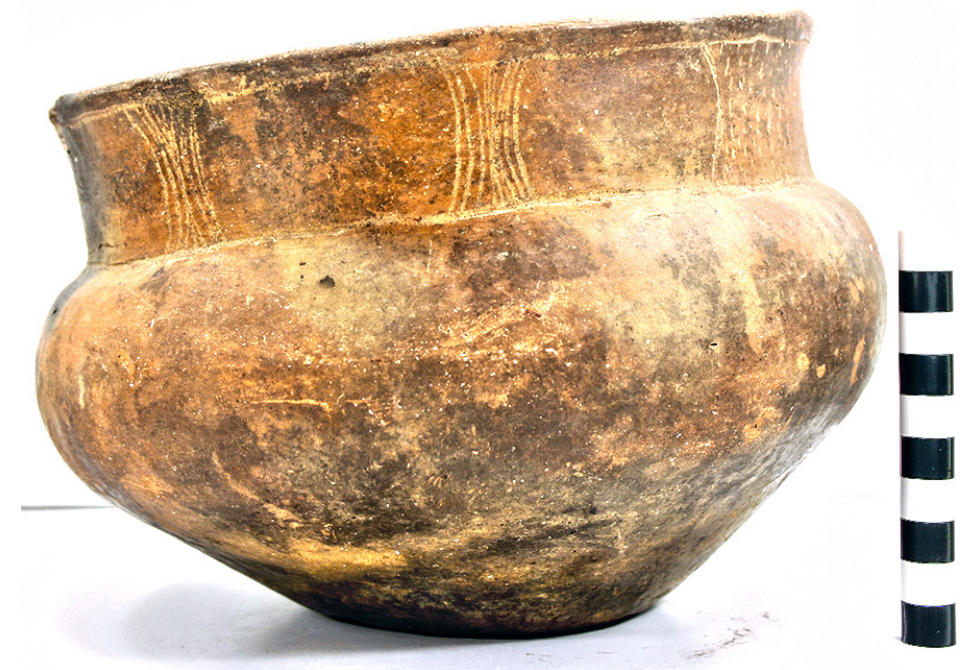

Figure 23. Poynor Engraved, var. Hood carinated bowl from the H. C. Slider site. 


\section{Darco Site, Harrison County, Texas}

SITE NAME OR SITE NUMBER: Darco site

VESSEL NO.: 2003.08.3243

VESSEL FORM: Jar

NON-PLASTICS AND PASTE: grog

RIM AND LIP FORM: Direct rim and rounded lip

CORE COLOR: $\mathrm{F}$ (fired in a reducing environment and cooled in the open air)

INTERIOR SURFACE COLOR: dark reddish-brown

EXTERIOR SURFACE COLOR: brown

WALL THICKNESS (IN MM): rim, $5.8 \mathrm{~mm}$

INTERIOR SURFACE TREATMENT: smoothed

EXTERIOR SURFACE TREATMENT: none

HEIGHT (IN CM): 16.0

ORIFICE DIAMETER (IN CM): 13.6

DIAMETER AT BOTTOM OF RIM OR NECK (IN CM): 13.3

BASE DIAMETER (IN CM) AND SHAPE OF

BASE: $8.2 \mathrm{~cm}$, circular and flat

ESTIMATED VOLUME (IN LITERS): 1.3

DECORATION (INCLUDING MOTIF AND ELEMENTS WHEN APPARENT): The rim has three rows of crescent-shaped fingernail punctations between horizontal incised lines. The vessel body has at least 11 horizontal rows of tool punctations that extend to the vessel base (Figure 24).

PIGMENT USE AND LOCATION ON VESSEL: none

TYPE AND VARIETY (IF KNOWN): Weches Fingernail Impressed (see Suhm and Jelks 1962:Plate 77)

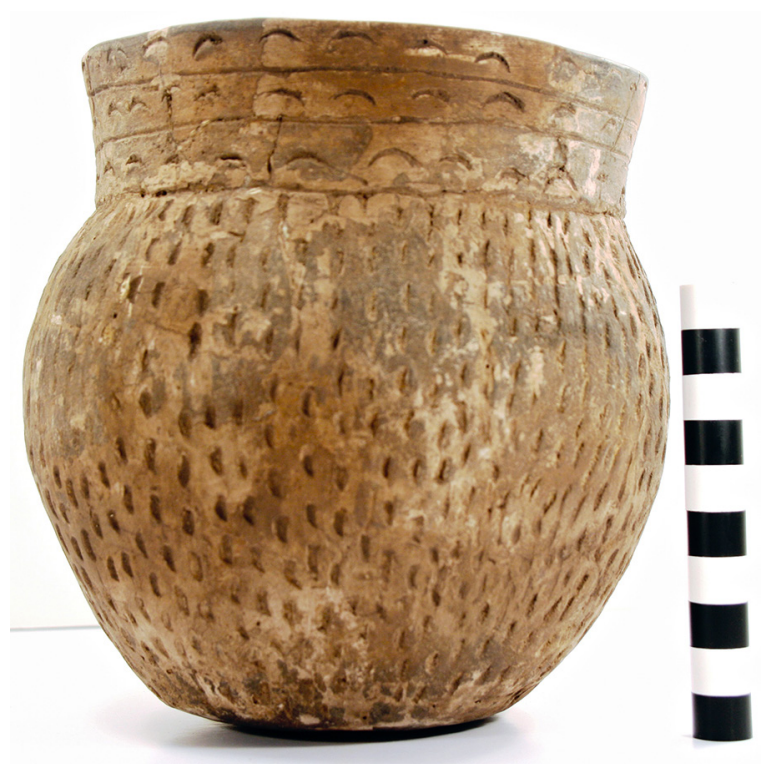

Figure 24. Weches Fingernail Impressed jar from the Darco site. 
SITE NAME OR SITE NUMBER: Darco site

VESSEL NO.: 2003.08.3244

VESSEL FORM: Bowl with four rim peaks

NON-PLASTICS AND PASTE: grog

RIM AND LIP FORM: Direct rim and rounded lip

CORE COLOR: $\mathrm{G}$ (fired in a reducing environment and cooled in the open air)

INTERIOR SURFACE COLOR: very dark grayish-brown

EXTERIOR SURFACE COLOR: brown

WALL THICKNESS (IN MM): rim, $6.3 \mathrm{~mm}$

INTERIOR SURFACE TREATMENT: smoothed

EXTERIOR SURFACE TREATMENT: smoothed

HEIGHT (IN CM): $8.2 \mathrm{~cm}$; height at rim peak is $10.2 \mathrm{~cm}$

ORIFICE DIAMETER (IN CM): 13.3

DIAMETER AT BOTTOM OF RIM OR NECK (IN CM): 13.3

BASE DIAMETER (IN CM) AND SHAPE OF BASE: $7.6 \mathrm{~cm}$, circular and rounded

ESTIMATED VOLUME (IN LITERS): 0.4

DECORATION (INCLUDING MOTIF AND ELEMENTS WHEN APPARENT): The rim of the vessel has four horizontal incised lines. The vessel upper body has eight upper and lower sets of concentric semi-circles filled with rows of cane punctations (Figure 25).

PIGMENT USE AND LOCATION ON VESSEL: none

TYPE AND VARIETY (IF KNOWN): Crockett Curvilinear Incised

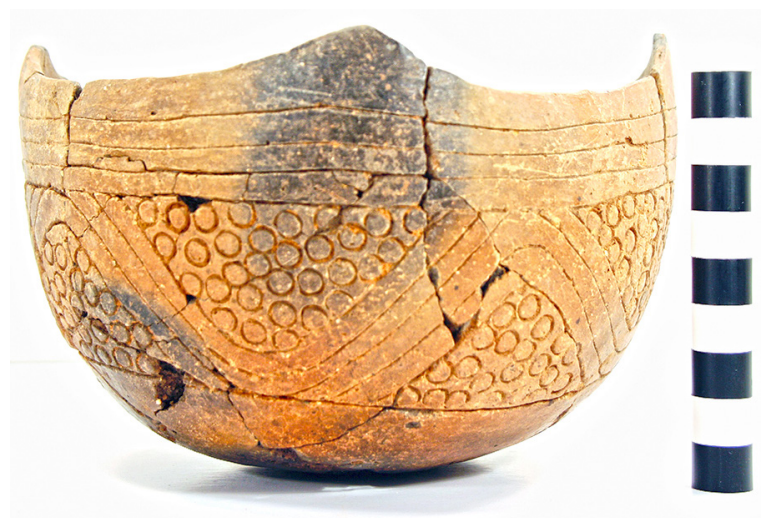

Figure 25. Crockett Curvilinear Incised bowl from the Darco site. 
SITE NAME OR SITE NUMBER: Darco site

VESSEL NO.: 2003.08.3245

VESSEL FORM: Carinated bowl

NON-PLASTICS AND PASTE: grog

RIM AND LIP FORM: Direct rim and rounded lip

CORE COLOR: $\mathrm{G}$ (fired in a reducing environment and cooled in the open air)

INTERIOR SURFACE COLOR: very dark grayish-brown

EXTERIOR SURFACE COLOR: brown; fire clouds on the body

WALL THICKNESS (IN MM): rim, $6.6 \mathrm{~mm}$

INTERIOR SURFACE TREATMENT: burnished

EXTERIOR SURFACE TREATMENT: burnished

HEIGHT (IN CM): 6.0

ORIFICE DIAMETER (IN CM): 23.4

DIAMETER AT BOTTOM OF RIM OR NECK (IN CM): 23.0

BASE DIAMETER (IN CM) AND SHAPE OF BASE: $7.6 \mathrm{~cm}$, circular and rounded

ESTIMATED VOLUME (IN LITERS): 0.8

DECORATION (INCLUDING MOTIF AND ELEMENTS WHEN APPARENT): The rim panel has alternating sets of closely-spaced vertical and diagonal (left to right) engraved lines, with upper and lower excised triangle elements set between the vertical and diagonal engraved lines (Figure 26).

PIGMENT USE AND LOCATION

ON VESSEL: none

TYPE AND VARIETY (IF

KNOWN): Holly Fine Engraved

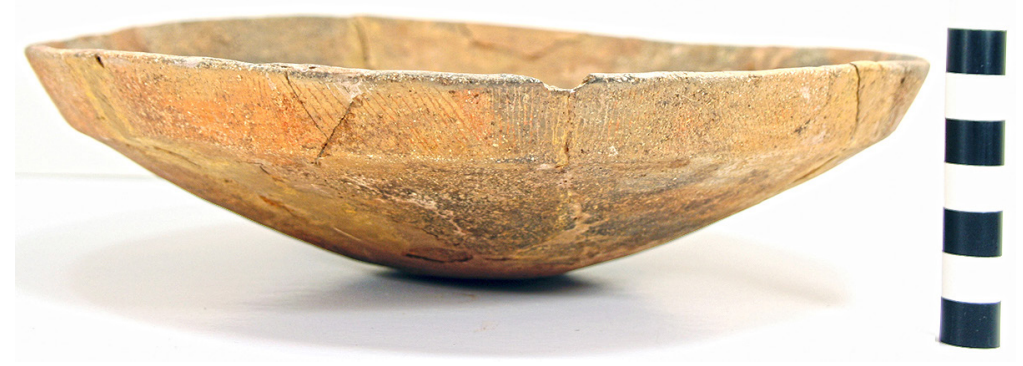

Figure 26. Holly Fine Engraved carinated bowl from the Darco site. 
SITE NAME OR SITE NUMBER: Darco site

VESSEL NO.: 2003.08.3246

VESSEL FORM: Bottle

NON-PLASTICS AND PASTE: grog and bone

RIM AND LIP FORM: Direct rim and flat lip

CORE COLOR: B (fired and cooled in a reducing environment)

INTERIOR SURFACE COLOR: black

EXTERIOR SURFACE COLOR: black

WALL THICKNESS (IN MM): rim, $5.9 \mathrm{~mm}$; body, $7.1 \mathrm{~mm}$

INTERIOR SURFACE TREATMENT: none

EXTERIOR SURFACE TREATMENT: burnished

HEIGHT (IN CM): neck height, $11.0 \mathrm{cml}$ body height, $9.9 \mathrm{~cm}$

ORIFICE DIAMETER (IN CM): 3.2

DIAMETER AT BOTTOM OF RIM OR NECK (IN CM): 6.4

BASE DIAMETER (IN CM) AND SHAPE OF

BASE: $6.4 \mathrm{~cm}$, circular and rounded

ESTIMATED VOLUME (IN LITERS): ca. 0.6

DECORATION (INCLUDING MOTIF AND ELEMENTS WHEN APPARENT): There are three horizontal engraved lines at the top of the bottle neck, and four horizontal engraved lines at the top of the vessel body. The remainder of the vessel body has four sets of concentric engraved lines divided by sets of four vertical engraved lines (Figure 27).

PIGMENT USE AND LOCATION ON VESSEL: none

TYPE AND VARIETY (IF KNOWN): Spiro Engraved

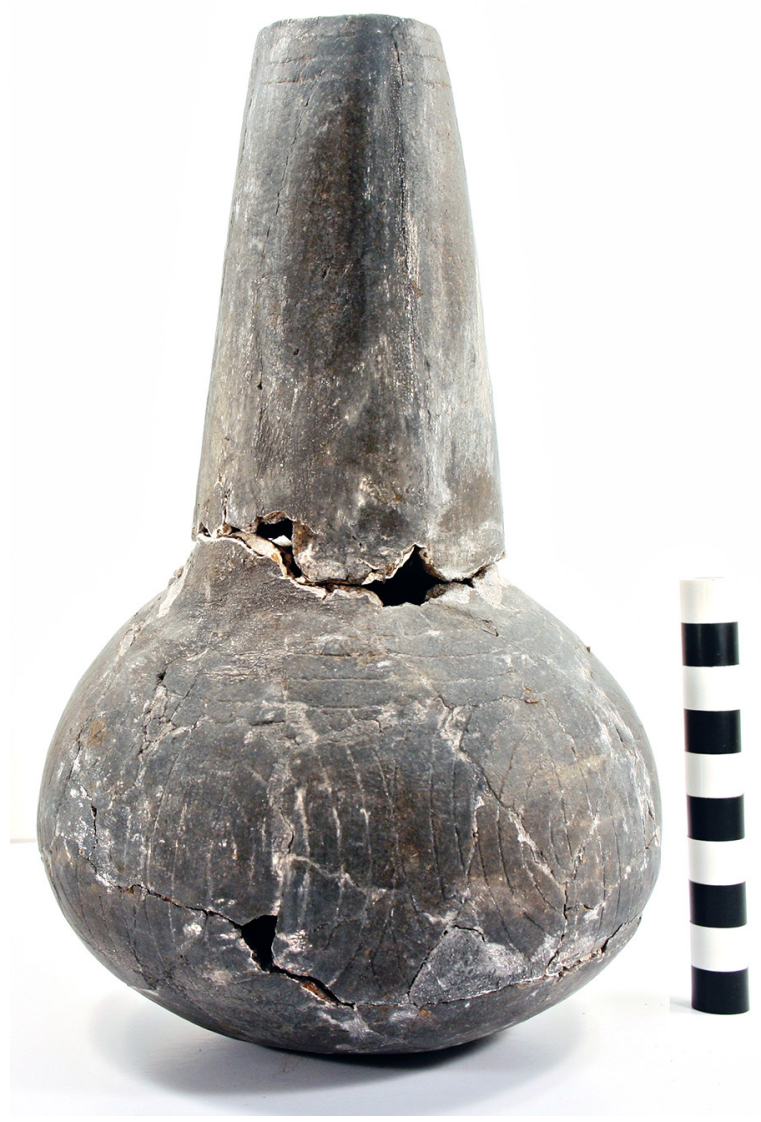

Figure 27. Spiro Engraved bottle from the Darco site. 


\section{Tejas Village Site, Harrison County, Texas}

The Tejas Village site is an ancestral Caddo settlement at Lake O' the Pines in the Big Cypress Creek drainage basin. There is a single partially reconstructed ceramic vessel in the Buddy Jones collection from the site.

SITE NAME OR SITE NUMBER: Tejas Village site

VESSEL NO.: -

VESSEL FORM: Carinated bowl

NON-PLASTICS AND PASTE: grog

RIM AND LIP FORM: Direct rim and rounded lip

CORE COLOR: B (fired and cooled in a reducing environment)

INTERIOR SURFACE COLOR: black

EXTERIOR SURFACE COLOR: black

WALL THICKNESS (IN MM): rim, $5.9 \mathrm{~mm}$; body, $7.1 \mathrm{~mm}$

INTERIOR SURFACE TREATMENT: burnished

EXTERIOR SURFACE TREATMENT: burnished

HEIGHT (IN CM): rim panel height, $3.2 \mathrm{~cm}$

ORIFICE DIAMETER (IN CM): 17.5

DIAMETER AT BOTTOM OF RIM OR NECK (IN CM): 17.5

BASE DIAMETER (IN CM) AND SHAPE OF BASE: N/A

ESTIMATED VOLUME (IN LITERS): 0.4+

\section{DECORATION (INCLUDING MOTIF AND}

ELEMENTS WHEN APPARENT): The rim panel has sets of horizontal and rectilinear lines and narrow zones with hatched or ticked lines. There are single horizontal engraved lines with tick marks beneath the lip and at the carination. The horizontal and rectilinear lines and zones are divided by vertical columns of semi-circular and diagonal opposed engraved lines (Figure 28).

PIGMENT USE AND LOCATION ON VESSEL: none TYPE AND VARIETY (IF KNOWN): Glassell Engraved

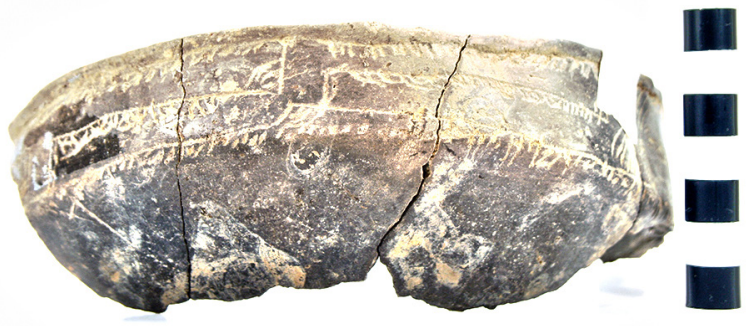

Figure 28. Glassell Engraved carinated bowl from the Tejas Village site, Harrison County, Texas. 


\section{Unknown East Texas Sites}

SITE NAME OR SITE NUMBER: Unknown

VESSEL NO.: 2

VESSEL FORM: Globular carinated bowl

NON-PLASTICS AND PASTE: grog

RIM AND LIP FORM: Direct rim and rounded lip

CORE COLOR: $\mathrm{H}$ (fired in a reducing environment and cooled in the open air)

INTERIOR SURFACE COLOR: dark yellowish-brown; fire clouds on the rim and body

EXTERIOR SURFACE COLOR: black

WALL THICKNESS (IN MM): rim, $4.8 \mathrm{~mm}$

INTERIOR SURFACE TREATMENT: burnished

EXTERIOR SURFACE TREATMENT: burnished

HEIGHT (IN CM): 11.2

ORIFICE DIAMETER (IN CM): 11.0

DIAMETER AT BOTTOM OF RIM OR NECK (IN CM): 11.0

BASE DIAMETER (IN CM) AND SHAPE OF BASE: $5.2 \mathrm{~cm}$, circular and flat

ESTIMATED VOLUME (IN LITERS):

0.7

DECORATION (INCLUDING MOTIF AND ELEMENTS WHEN APPARENT):

The rim panel has five sets of negative ovals defined by sets of closely-spaced vertical-curvilinear engraved lines (Figure 29).

PIGMENT USE AND LOCATION ON VESSEL: none

TYPE AND VARIETY (IF KNOWN):

Poynor Engraved, var. Cook

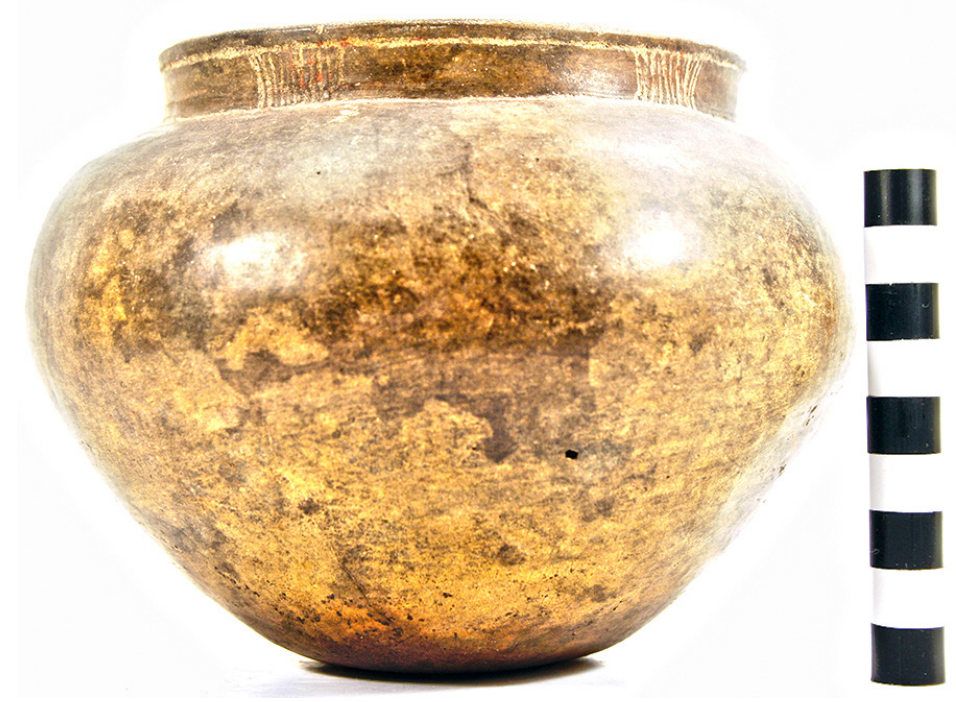

Figure 29. Poynor Engraved, var. Cook carinated bowl in the Buddy Jones collection. 
SITE NAME OR SITE NUMBER: Unknown

VESSEL NO.: 3

VESSEL FORM: Jar with four noded/podal supports ( $7 \mathrm{~mm}$ in diameter) on the base (Figure 30)

NON-PLASTICS AND PASTE: grog

RIM AND LIP FORM: Direct rim and flat lip

CORE COLOR: $\mathrm{F}$ (fired in a reducing environment and cooled in the open air)

INTERIOR SURFACE COLOR: yellowish-brown

EXTERIOR SURFACE COLOR: yellowish-brown; fire clouds on the rim, body, and base

WALL THICKNESS (IN MM): rim, $9.7 \mathrm{~mm}$

INTERIOR SURFACE TREATMENT: none

EXTERIOR SURFACE TREATMENT: smoothed

HEIGHT (IN CM): 3.9

ORIFICE DIAMETER (IN CM): 5.4

DIAMETER AT BOTTOM OF RIM OR NECK (IN CM): 5.4

BASE DIAMETER (IN CM) AND SHAPE OF BASE: $3.1 \mathrm{~cm}$, circular and flat ESTIMATED VOLUME (IN LITERS): 0.1

DECORATION (INCLUDING MOTIF AND ELEMENTS WHEN APPARENT): There is a single row of tool punctations beneath the lip (Figure 30).

PIGMENT USE AND LOCATION ON VESSEL: none

TYPE AND VARIETY (IF KNOWN): Unidentified utility ware

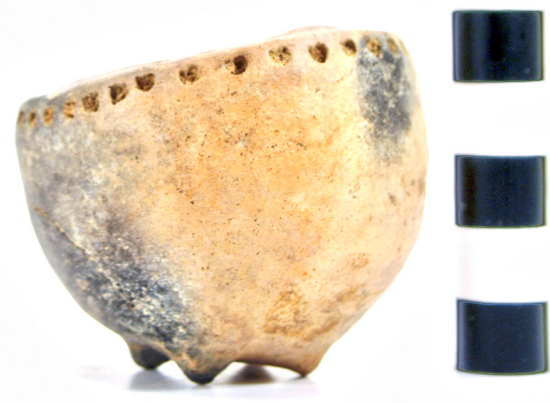

Figure 30. Tool punctated jar from an unknown site in the Buddy Jones Collection. 
SITE NAME OR SITE NUMBER: Unknown

VESSEL NO.: 2003.08.3215

VESSEL FORM: Jar

NON-PLASTICS AND PASTE: grog

RIM AND LIP FORM: Direct rim and rounded lip

CORE COLOR: $\mathrm{F}$ (fired in a reducing environment and cooled in the open air)

INTERIOR SURFACE COLOR: dark yellowish-brown; fire clouds on the rim and base

EXTERIOR SURFACE COLOR: dark yellowish-brown; fire clouds on the rim, body, and base

WALL THICKNESS (IN MM): rim, $5.4 \mathrm{~mm}$

INTERIOR SURFACE TREATMENT: smoothed

EXTERIOR SURFACE TREATMENT: none

HEIGHT (IN CM): 7.6

ORIFICE DIAMETER (IN CM): 11.4

DIAMETER AT BOTTOM OF RIM OR NECK (IN CM): 11.3

BASE DIAMETER (IN CM) AND SHAPE OF BASE: $5.1 \mathrm{~cm}$, circular and flat

ESTIMATED VOLUME (IN LITERS): 0.5

DECORATION (INCLUDING MOTIF AND ELEMENTS WHEN APPARENT): Plain (Figure 31)

PIGMENT USE AND LOCATION ON VESSEL: none

TYPE AND VARIETY (IF KNOWN):

Unidentified plain ware

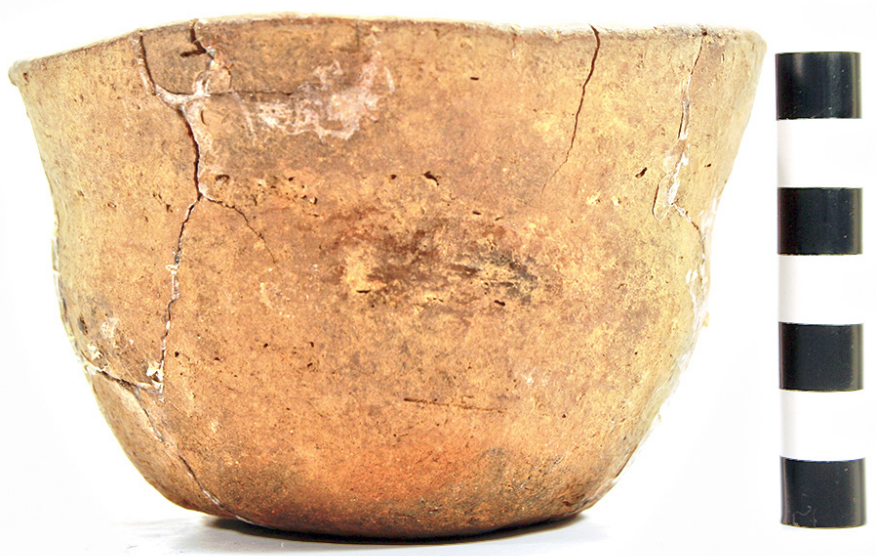

Figure 31. Plain jar in the Buddy Jones Collection. 
SITE NAME OR SITE NUMBER: Unknown site

VESSEL NO.: 2003.08.3224

VESSEL FORM: Carinated bowl

NON-PLASTICS AND PASTE: grog

RIM AND LIP FORM: Inverted rim and rounded lip

CORE COLOR: $\mathrm{F}$ (fired in a reducing environment and cooled in the open air)

INTERIOR SURFACE COLOR: yellowish-brown; fire clouds on the rim, body, and base

EXTERIOR SURFACE COLOR: yellowish-brown; fire clouds on the body

WALL THICKNESS (IN MM): rim, $5.2 \mathrm{~mm}$

INTERIOR SURFACE TREATMENT: smoothed

EXTERIOR SURFACE TREATMENT: burnished

HEIGHT (IN CM): 4.4

ORIFICE DIAMETER (IN CM): 8.3

DIAMETER AT BOTTOM OF RIM OR NECK (IN CM): 9.4

BASE DIAMETER (IN CM) AND SHAPE OF BASE: $5.1 \mathrm{~cm}$, circular and flat

ESTIMATED VOLUME (IN LITERS): 0.2

DECORATION (INCLUDING MOTIF AND

ELEMENTS WHEN APPARENT): The rim panel has two sets of vertical S-shaped elements, two sets of narrow cross-hatched rectangular elements, and slanting scrolls with upper and lower scroll fill zones with hooked ends between the vertical and horizontal elements (Figure 32).

PIGMENT USE AND LOCATION ON VESSEL: red pigment in engraved lines

TYPE AND VARIETY (IF KNOWN): Ripley Engraved, var. unspecified

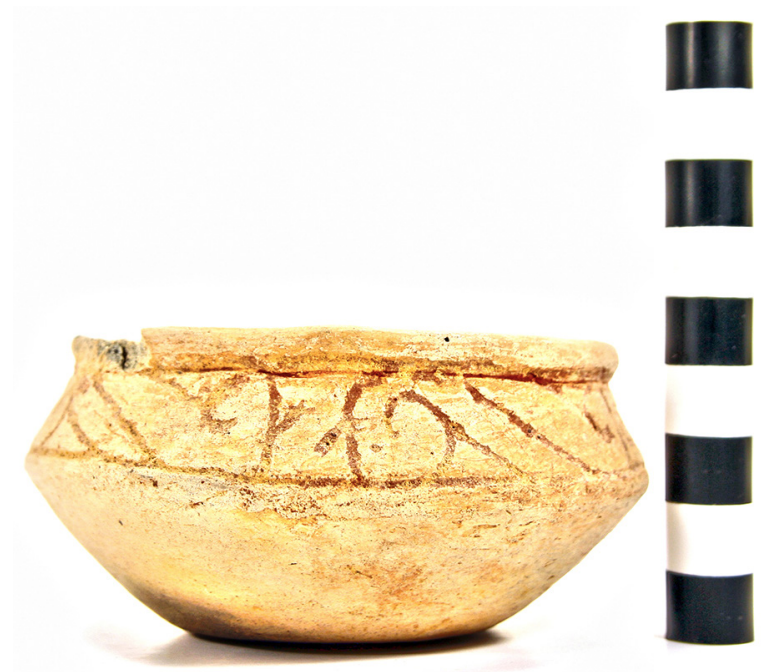

Figure 32. Ripley Engraved, var. unspecified carinated bowl in the Buddy Jones Collection. 
SITE NAME OR SITE NUMBER: Unknown

VESSEL NO.: 2003.08.3228

VESSEL FORM: Effigy bowl with possible deer effigy head $(20.3 \mathrm{~mm}$ in height at the head; $32.8 \mathrm{~mm}$ in height at the crest of the effigy head) (Figure 33a)

NON-PLASTICS AND PASTE: grog

RIM AND LIP FORM: Direct rim and rounded lip

CORE COLOR: $\mathrm{G}$ (fired in a reducing environment and cooled in the open air)

INTERIOR SURFACE COLOR: grayish-brown

EXTERIOR SURFACE COLOR: yellowish-brown

WALL THICKNESS (IN MM): rim, $6.4 \mathrm{~mm}$; body, $7.0 \mathrm{~mm}$

INTERIOR SURFACE TREATMENT: none

EXTERIOR SURFACE TREATMENT: smoothed

HEIGHT (IN CM): 4.5; $7.1 \mathrm{~cm}$ at the top of the effigy head

ORIFICE DIAMETER (IN CM): 6.9

DIAMETER AT BOTTOM OF RIM OR NECK (IN CM): N/A

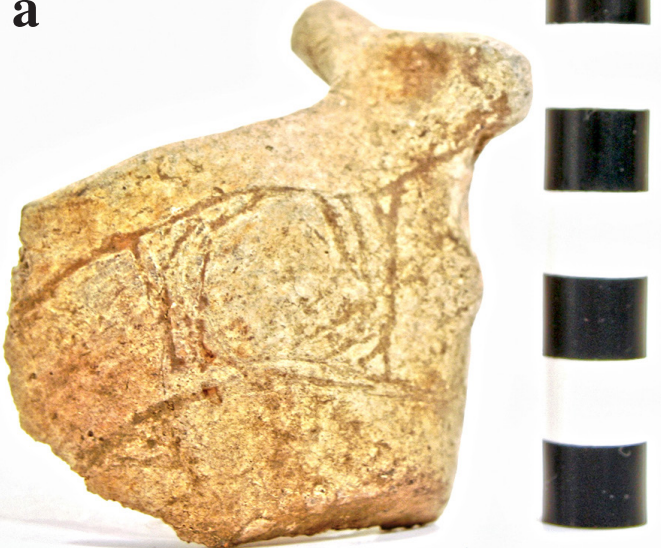

BASE DIAMETER (IN CM) AND SHAPE OF BASE: N/A

ESTIMATED VOLUME (IN LITERS): 0.1

DECORATION (INCLUDING MOTIF AND ELEMENTS

WHEN APPARENT): The rim has two horizontal engraved lines as well as a $21.5 \mathrm{~mm}$ high panel on the vessel body with hatched pendant triangle elements, squares with hatched corners and negative ovals, and a single appliqued node underneath the effigy head (Figure 33b).

PIGMENT USE AND LOCATION ON VESSEL: none

TYPE AND VARIETY (IF KNOWN): Hood Engraved, var. Cook

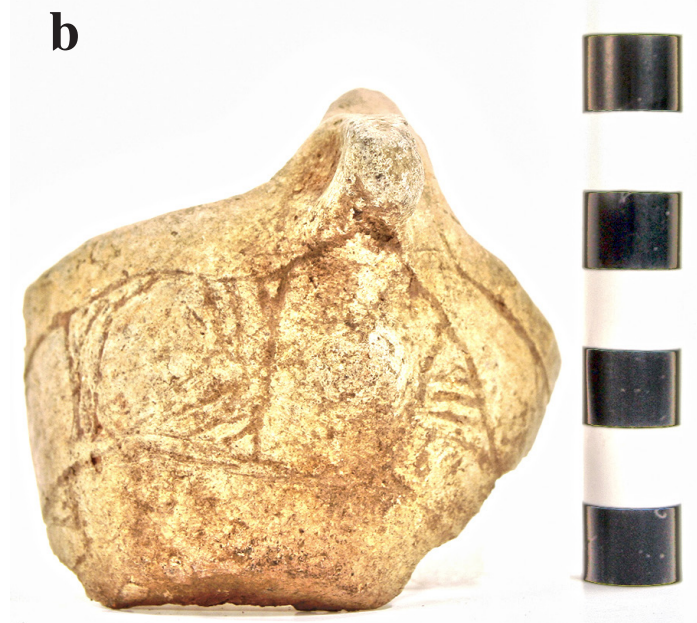

Figure 33. Hood Engraved, var. Cook effigy bowl in the Buddy Jones Collection: a, side view of effigy head; $b$, engraved motif. 
SITE NAME OR SITE NUMBER: Unknown

VESSEL NO.: 2003.08.3231

VESSEL FORM: Bottle with a spool neck (Figure 34)

NON-PLASTICS AND PASTE: grog

RIM AND LIP FORM: Everted rim and rounded lip

CORE COLOR: A (fired and cooled in an oxidizing environment)

INTERIOR SURFACE COLOR: yellowish-brown

EXTERIOR SURFACE COLOR: yellowish-brown; fire clouds on the rim, body, and base

WALL THICKNESS (IN MM): rim, $5.0 \mathrm{~mm}$

INTERIOR SURFACE TREATMENT: none

EXTERIOR SURFACE TREATMENT: burnished

HEIGHT (IN CM): 12.7

ORIFICE DIAMETER (IN CM): 4.8

DIAMETER AT BOTTOM OF RIM OR NECK (IN CM): 4.6; maximum body diameter is $9.2 \mathrm{~cm}$

BASE DIAMETER (IN CM) AND SHAPE OF

BASE: $5.8 \mathrm{~cm}$, circular and flat

ESTIMATED VOLUME (IN LITERS): 0.3

DECORATION (INCLUDING MOTIF AND ELEMENTS WHEN APPARENT): The vessel body has a series of interlocking curvilinear engraved scroll lines between upper and lower triangle elements and curvilinear lines (Figure 34). The vessel body is defined by single upper and lower horizontal engraved lines.

PIGMENT USE AND LOCATION ON VESSEL: none

TYPE AND VARIETY (IF KNOWN): Taylor Engraved

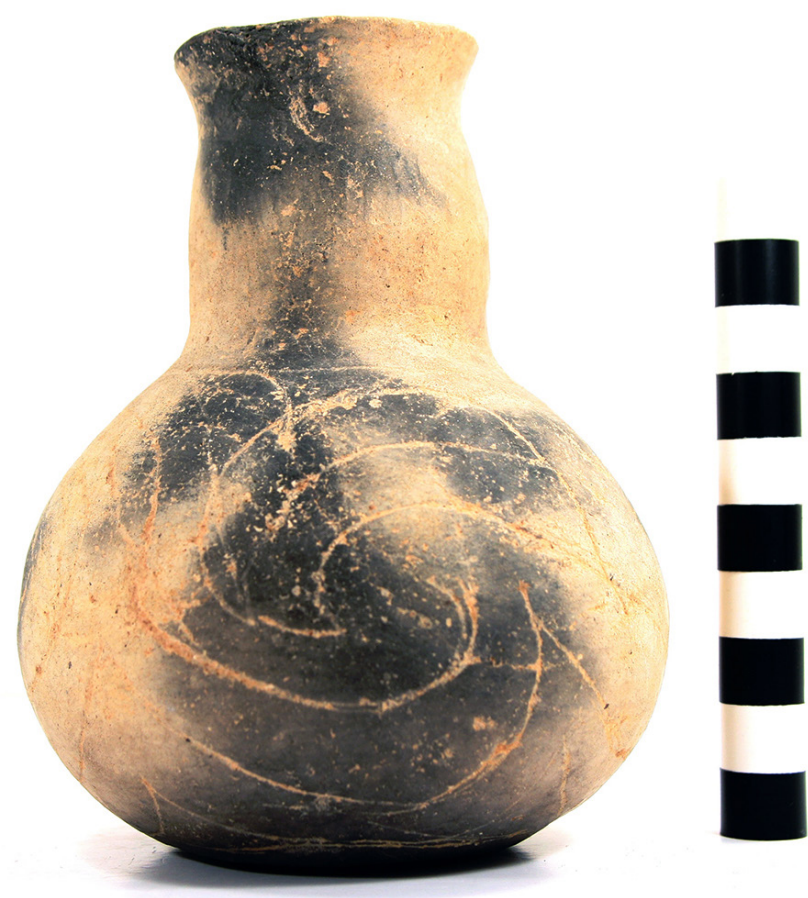

Figure 34. Taylor Engraved bottle in the Buddy Jones Collection from an unknown site. 


\section{Summary and Conclusions}

Thirty-three ancestral Caddo ceramic vessels were recently added to the Buddy Jones Collection at the Gregg County Historical Museum in Longview, Texas. We documented these vessels in April 2018. They are from the Pipe site ( $\mathrm{n}=12$ vessels, 41AN67, see Perttula 2011b), the Mud Creek site in Cherokee County ( $n=4$ vessels, see Perttula and Nelson 2013a), the H. C. Slider site in Cherokee County $(n=6$ vessels, see Perttula and Nelson 2013b), the Darco site in the Sabine River basin in Harrison County $(n=4)$, and the Tejas Village site in Harrison County ( $n=1$ vessel). The provenience of the other six vessels is unknown at the present time.

The vessels (and many of the decorated sherds, see Perttula 2018a) from the Darco site are from a Formative to Early Caddo period occupation dating between ca. A.D. 850-1200. They include Weches Fingernail Impressed, Crockett Curvilinear Incised, Holly Fine Engraved, and Spiro Engraved vessels; sherds from the site are also from Pennington Punctated Incised and French Fork Incised vessels.

The ceramic vessels from the Pipe, Mud Creek, and H. C. Slider sites, all in the Neches River basin, are from Late Caddo period Frankston phase burial features dating from ca. A.D. 1400-1560. Identified ceramic types at the Pipe site include Poynor Engraved, var. Cook, var. Lang, var. I, and var. unspecified vessels, as well as Maydelle Incised and Hood Engraved, var. Hood jars and bowls. Ceramic vessel sherds are from Poynor Engraved, Hume Engraved, Maydelle Incised, Bullard Brushed, Killough Pinched, and La Rue Neck Banded vessels (see Perttula 2011b). At the Mud Creek site, there are a total of eight vessels in the collection, those documented by Perttula and Nelson (2013a) and those documented herein. They include Poynor Engraved, var. Blackburn, var. Hood, and var. L carinated bowls and bottles and Hood Engraved, var. Hood and var. Mud Creek (a new variety) effigy bowls. The 11 vessels from the H. C. Slider site, including five documented previously by Perttula and Nelson (2013b), include a Hood Engraved effigy bowl, two Killough Pinched jars, a Bullard Brushed jar, two Hume Engraved bottles, a Poynor Engraved, var. unspecified bottle, two unique engraved and grooved bottles, and Poynor Engraved, var. A and var. Hood carinated bowls.

The one remaining ceramic vessel from a known site is a Glassell Engraved carinated bowl from the Late Caddo period Titus phase occupation of the Tejas Village site at Lake O' the Pines in the Big Cypress Creek drainage. Glassell Engraved is a distinctive fine ware made by Red River Caddo peoples during the Belcher phase (ca. A.D. 1500-1680), and it is rarely present in Titus phase sites: 0.8 percent of the more than 480 vessels at the nearby H. R. Taylor site (41HS3) are Glassell Engraved vessels (Perttula 2018b).

\section{Acknowledgments}

We thank Patti Haskins of the Gregg County Historical Museum in Longview, Texas for the opportunity to document these vessels in the Buddy Jones collection. Lance Trask prepared Figure 1 in the article. The vessel photographs were taken by Bo Nelson.

\section{References Cited}

Anderson, K. M., K. Gilmore, O. F. McCormick III, and E. P. Morenon

1974 Archaeological Investigations at Lake Palestine, Texas. Contributions in Anthropology No. 11. Department of Anthropology, Southern Methodist University, Dallas.

Brown, J. A.

1996 The Spiro Ceremonial Center: The Archaeology of Arkansas Valley Caddoan Culture in Eastern Oklahoma. 2 Vols. Memoirs No. 29. Museum of Anthropology, The University of Michigan, Ann Arbor. 
Ferring, C. R. and T. K. Perttula

1987 Defining the Provenance of Red-Slipped Pottery from Texas and Oklahoma by Petrographic Methods. Journal of Archaeological Science 14:437-456.

Fields, R. C., V. L. Hatfield, D. Burden, E. F. Gadus, M. C. Wilder, and K. W. Kibler

2014 Testing and Data Recovery Excavations at 11 Native American Archeological Sites along the U.S. Highway 271 Mount Pleasant Relief Route, Titus County, Texas. 2 Vols. Reports of Investigations No. 168. Prewitt and Associates, Inc., Austin.

Perttula, T. K.

2011a The Ceramic Artifacts from the Lang Pasture Site (41AN38) and the Place of the Site within an Upper Neches River Basin Caddo Ceramic Tradition. In Archeological Investigations at the Lang Pasture Site (41AN38) in the Upper Neches River Basin of East Texas, assembled and edited by T. K. Perttula, D. B. Kelley, and R. A. Ricklis, pp. 145-320. Archeological Studies Program Report No. 129, Texas Department of Transportation, Environmental Affairs Division, Austin.

2011b The Pipe Site, a Late Caddo Site at Lake Palestine in Anderson County, Texas. Journal of Northeast Texas Archaeology 35:47-80.

2015 East Texas Caddo Ceramic Sherd Database. Journal of Northeast Texas Archaeology 51:1-46.

2018a Caddo Ceramic Vessel Sherd Assemblages from Sites in the Sabine River Basin, Harrison County, Texas. Journal of Northeast Texas Archaeology 79 (this volume).

2018b Ceramic Vessels and Other Funerary Objects in the H. R. Taylor Cemetery (41HS3), Harrison County, Texas. Special Publication No. 46. Friends of Northeast Texas Archaeology, Austin and Pittsburg.

Perttula, T. K. (editor)

2005 Archeological Investigations at the Pilgrim's Pride Site (41CP304), a Titus Phase Community in the Big Cypress Creek Basin, Camp County, Texas. 2 Vols. Report of Investigations No. 30. Archeological \& Environmental Consultants, LLC, Austin.

Perttula, T. K. and B. Nelson

2013a The Mud Creek Site in the Angelina River Basin, Cherokee County, Texas. Journal of Northeast Texas Archaeology 41:31-39.

2013b A Frankston Phase Settlement and Cemetery at the H. C. Slider Site on the Neches River in Cherokee County, Texas. Journal of Northeast Texas Archaeology 41:41-56.

Rice, P. M.

1987 Pottery Analysis: A Sourcebook. University of Chicago Press, Chicago.

Skibo, J. M.

1992 Pottery Function: A Use-Alteration Perspective. Plenum Press, New York.

Suhm, D. A. and E. B. Jelks (editor)

1962 Handbook of Texas Archeology: Type Descriptions. Special Publication No. 1, Texas Archeological Society, and Bulletin No. 4, Texas Memorial Museum, Austin.

Teltser, P. A.

1993 An Analytic Strategy for Studying Assemblage-Scale Ceramic Variation: A Case Study from Southeast Missouri. American Antiquity 58(3):530-543. 